$$
\text { PNNL- } 11203
$$

\title{
Efficiency and Supply Resource Options for the Upgrade of the Plzen̆ District Heating System
}

Prepared by

Pacific Northwest National Laboratory

SEVEn

Tecogen

Prepared: November 1995

Printed: June 1996

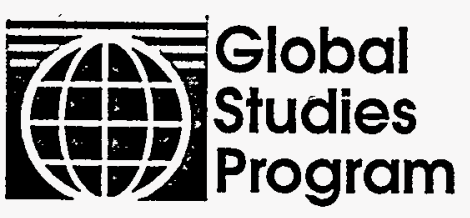

Pacific Northwest National Laboratory Advanced International Studies
RECFIVED

nгT $\cap 41996$

;

RECEIVED

OCT 041996

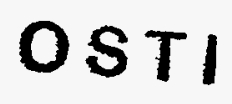

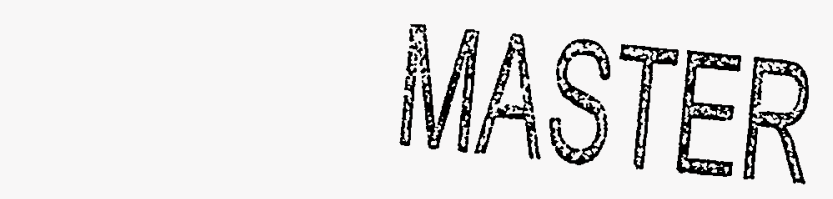




\title{
DISCLAIMER
}

This report was prepared as an account of work sponsored by an agency of the United States Government. Neither the United States Government nor any agency thereof, nor Battelle Memorial institute, nor any of their employees, makes any warranty, express or implied, or assumes any legal liability or responsibility for the accuracy, completeness, or usefulness of any information, apparatus, product, or process disclosed, or represents that its use would not infringe privately owned rights. Reference herein to any specific commercial product, process, or service by trade name, trademark, manufacturer, or otherwise does not necessarily constitute or imply its endorsement, recommendation, or favoring by the United States Government or any agency thereof, or Battelle Memorial Institute. The views and opinions of authors expressed herein do not necessarily state or reflect those of the United States Government or any agency thereof.

\author{
PACIFIC NORTHWEST NATIONAL LABORATORY \\ operated by \\ BATTELLE \\ for the \\ UNITED STATES DEPARTMENT OF ENERGY \\ under Contract DE-ACO6-76RLO 1830
}

This document was printed on recycled paper. 
Efficiency and Supply Resource Options for the Upgrade of the Plzeñ District Heating System

Prepared by

Pacific Northwest National Laboratory

SEVEn

Tecogen

June 1996

Prepared for the U.S. Department of Energy under Contract DE-AC06-76RLO 1830

Pacific Northwest National Laboratory

Washington, DC 20024 
DISCLAIMER

Portions of this document may be illegible in electronic image products. Images are produced from the best available original document. 


\section{Summary}

This assessment examined options for meeting the district heating system steam and hot water heating loads associated with the Plzen Central Heating Plant, two interconnected boilers serving the Kosutka and Bory regions, and the distributed systems in the Letna/Doubravka and Svetovar regions. The assessment methodology applied integrated resource planning principles to combine the separate supply and demand-side assessments conducted for the system.

Four system load scenarios were examined-high and low growth with and without programmatic efficiency. Hot water loads ranged from the current level of 277 megawatts thermal (MW) to $320 \mathrm{MW}_{\mathrm{t}}$ in a high growth scenario without efficiency to $253 \mathrm{MW}_{\mathrm{t}}$ in a low growth scenario with programmatic efficiency. The high growth scenario includes an addition of approximately $50 \mathrm{MW}_{\mathrm{t}}$ load from the connection of distributed boilers. An additional $250 \mathrm{MW}_{\mathrm{t}}$ load served by distributed boilers may provide additional potential for system expansion. Steam loads are projected to increase from $93 \mathrm{MW}_{\mathrm{t}}$ to $100 \mathrm{MW}_{\mathrm{t}}$ in the high growth scenario and decrease to $89 \mathrm{MW}_{\mathrm{t}}$ in the low growth scenario.

Two system expansion cases were structured for the assessment. The moderate system expansion provided for the Heat Line East I connection to serve the Letna/Doubravka region and the full system expansion case further provided for the Heat Line East II connection to serve the Svetovar region. In the moderate system expansion case, the life of the Svetovar plant is extended to continue servicing that region as a stand-alone system.

Four central plant supply configurations providing for additional cogeneration capacity were applied to the load scenarios:

Coal 2003 Life extension to the existing facilities with introduction of new coal-fired cogeneration unit in 2003.

Coal 1997 Retirement of some existing units and introduction of a new coal-fired cogeneration unit in 1997.

$65 \mathrm{MW}$, Gas Retirement of some existing units and introduction of a new gas-fired cogeneration unit in 1997.

$60 \mathrm{MW}_{1}$ Gas Retirement of some existing units and introduction of a new gas-fired cogeneration unit in 1997.

The central plant configurations were sized to meet the high and low demand scenarios as necessary. 
Buildings sector efficiency potential was analyzed for the high and low load growth scenarios. Measures examined included weatherization, insulation, controls, and heat recovery. These measures are estimated to provide for customer level efficiency improvements of about $15 \%$ and reductions in capacity requirements of about $10 \%$.

The supply and efficiency options were integrated and characterized by capital requirements, levelized energy cost, typical household energy bill, and emissions for the four load growth scenarios and moderate and full system expansion cases as follows (the two gas-fired options are combined for this summary):

\section{Capital Requirements}

Coal 2003 Lowest, near-term (1993-2000) requirements at 800 million Crowns (Kc), about $40 \%$ of the next highest option, Coal 1997.

Lowest long-term (1993-2010) requirements at 2150 million $\mathrm{Kc}$, about $3 \%$ and $30 \%$ lower than the Coal 1997 configuration for the high and low load growth scenarios, respectively.

Coal 1997 Nearly equal to the $60 \mathrm{MW}$, gas-fired configuration and about $10 \%$ to $15 \%$ lower than the $65 \mathrm{MW}$, gas-fired configuration in the near and long term.

Gas 1997 Highest capital requirement, ranging from 2300 to 2540 million $\mathrm{Kc}$ for the long term.

Efficiency Requires about 500 million $\mathrm{Kc}$ in capital, 250 million $\mathrm{Kc}$ of it in the near term.

Full System

Expansion Requires about 54 million $\mathrm{Kc}$ in near term.

\section{Levelized Energy Cost (Combined Hot Water and Steam)}

Coal 2003 Lowest, about $160 \mathrm{Kc}$ /gigajoule (GJ) in the moderate system expansion case.

Coal 1997 Moderate, ranging from about 170 to $180 \mathrm{Kc} / \mathrm{GJ}$.

Gas 1997 Highest, ranging from about 200 to $215 \mathrm{Kc} / \mathrm{GJ}$.

Efficiency Increases price of any of the three options by approximately $20 \mathrm{Kc} / \mathrm{GJ}$.

Full System

Expansion Increases price by approximately $5 \mathrm{Kc} / \mathrm{GJ}$. 


\section{Residential Energy Bill}

Coal 2003 Lowest, about $6800 \mathrm{Kc} / \mathrm{yr}$ in moderate system expansion case.

Coal 1997 Moderate, ranging from 7100 to $7500 \mathrm{Kc} / \mathrm{yr}$.

Gas 1997 Highest, ranging from 9100 to $9900 \mathrm{Kc} / \mathrm{yr}$.

Efficiency Reduces bill about $300-400 \mathrm{Kc} / \mathrm{yr}$ for coal configurations and $500-600 \mathrm{Kc} / \mathrm{yr}$ for gas-fired configurations.

Full System

Expansion Increases bill by approximately $100-300 \mathrm{Kc} / \mathrm{yr}$.

\section{Emissions Reduction (Particulates, $\mathrm{SO}_{2}, \mathrm{NO}_{\mathrm{x}}$, and $\mathrm{CO}$ )}

The emissions reductions are based on levels expected from compliance with 1997 emissions requirements.

Coal 2003 Zero, serves as the base case, so reductions are realized only in the low load growth scenario.

.Coal 1997 Low, provides for approximately $1 \%$ reduction in all emissions.

Gas 1997 Highest reduction, $17 \%$ to $20 \%$ in $\mathrm{SO}_{2}, 12 \%$ to $16 \%$ in $\mathrm{NO}_{\mathrm{x}}, 4 \%$ in particulates, and $1 \%$ to $2 \%$ in $\mathrm{CO}$.

Efficiency Low, provides additional $3 \%$ reduction in $\mathrm{SO}_{2}$ and $\mathrm{NO}_{\mathrm{X}}, 1 \%$ to $2 \%$ in particulates, and $1 \%$ in $\mathrm{CO}$.

Full System

Expansion No appreciable change.

This assessment did not optimize the amount and timing of the supply and efficiency resources for meeting load at least cost; however, it is not expected that the relative differences and effects of the . resource options would change the comparisons discussed above.

The U.S. Agency for International Development provided funding for this assessment through a cooperative agreement with the U.S. Department of Energy. 


\section{Contents}

Summary $\quad \ldots \ldots \ldots \ldots \ldots \ldots \ldots \ldots \ldots \ldots \ldots \ldots \ldots \ldots \ldots \ldots \ldots \ldots \ldots$ iii

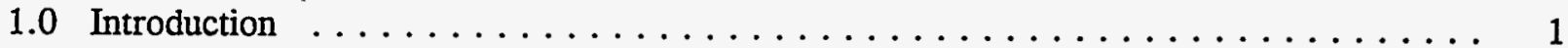

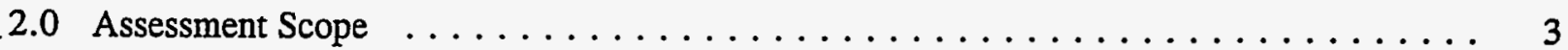

3.0 System Loads $\ldots \ldots \ldots \ldots \ldots \ldots \ldots \ldots \ldots \ldots \ldots \ldots \ldots \ldots$

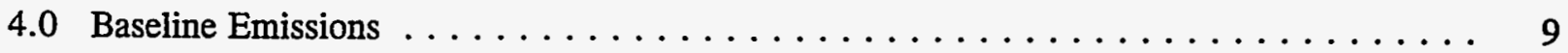

5.0 Supply Resources $\ldots \ldots \ldots \ldots \ldots \ldots \ldots \ldots \ldots \ldots \ldots \ldots \ldots \ldots \ldots \ldots$

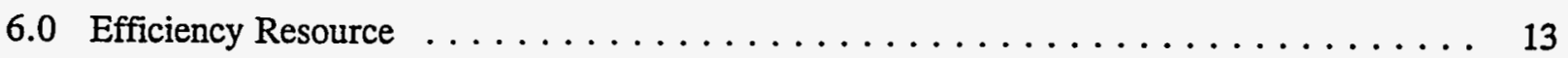

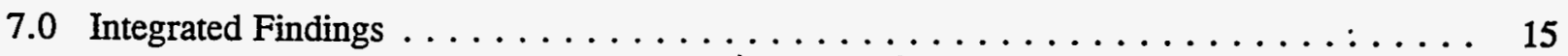

8.0 Related Publications $\ldots \ldots \ldots \ldots \ldots \ldots \ldots \ldots \ldots \ldots \ldots \ldots \ldots \ldots \ldots \ldots \ldots$

Appendix A - System Loads $\ldots \ldots \ldots \ldots \ldots \ldots \ldots \ldots \ldots \ldots \ldots \ldots \ldots \ldots$ A.1

Appendix B - Supply Resources $\ldots \ldots \ldots \ldots \ldots \ldots \ldots \ldots \ldots \ldots \ldots \ldots \ldots \ldots$

Appendix C - Load/Supply Capacity Margins $\ldots \ldots \ldots \ldots \ldots \ldots \ldots \ldots \ldots$

Appendix D - Analysis Assumptions $\ldots \ldots \ldots \ldots \ldots \ldots \ldots \ldots \ldots \ldots \ldots \ldots \ldots \ldots \ldots$ 


\section{Figure}

$1^{\cdot}$ Plzeň District Heating System Schematic $\ldots \ldots \ldots \ldots \ldots \ldots \ldots \ldots \ldots$

\section{Tables}

1 Hot Water and Steam Load Growth Scenarios by Peak Capacity (MW), 1992-1197,

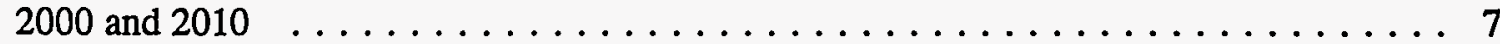

2 Emissions from Existing Generating Supply Resources (Tonnes/year), 1993 and Compliance with 1997 Regulations . . . . . . . . . . . . . . . . . . . . 9

3 Peak Capacity (MW) for Plzeñ Central Heating Plant Configuration, 1993-2000, 2005 and 2010

4 Economic and Environmental Attributes for Móderate System Load Expansion by Plant Configuration, High and Low Load Growth Without and With Efficiency . . . . . 16

5 Economic and Environmental Attributes for Full System Load Expansion by Central Plant Configuration, High and Low Load Growth Without and With Efficiency $\ldots \ldots 18$ 


\subsection{Introduction}

The City of Plzen in the Czech Republic is examining options for meeting the thermal energy requirements of its citizens, with consideration of economic and the environment factors. Major energy-related issues the City faces are

- The need to upgrade and/or replace the heat generation resources that supply the district heating system.

- The need to reduce emissions in order to comply with more stringent environmental regulations and improve air quality.

- The need to minimize consumer energy bills, particularly to accommodate the upcoming decontrol of energy prices.

The U.S. Agency for International Development, through the U.S. Department of Energy, provided technical support to assist the City with an analysis of energy supply and efficiency options for addressing these issues. The supply assessment examined heat generation alternatives with application to the central segment of the district system serving the City and limited connection of coalfired distributed boilers. The efficiency assessment examined the efficiency resource that exists in the space and water heat end-uses for the residential and non-residential buildings sectors and all fuel types. Readers interested in detailed information are referred to these two reports (see Section 8).

This report summarizes and integrates the results and findings from the supply and demand assessments and is organized as follows:

- Assessment Scope

- System Loads

- Baseline Emissions

- Supply Resources

- Efficiency Resource

- Integrated Findings

The intent of the integrated assessment is to present the analysis of the options examined to support the City's decision-making proceșs, not to provide specific recommendations or guidance for the City to follow. 



\subsection{Assessment Scope}

The existing district heating system serving the City consists of four segments as shown in Figure 1. The system provides steam for industrial customers and hot water for residential and nonresidential buildings and industrial customers.

The Central System consists of the Plzeñ cogeneration plant, the Kosutka hot water peaking plant, the Pivovary (brewery) steam plant, the Railway (Zos) steam plant, and the Bory plant, which provides steam for an industrial (hospital) load and hot water. The total hot water and steam generating capacity is about $360 \mathrm{MW}$ thermal $(\mathrm{MW})$.

The major consuming entities served by the Central System are buildings in the central portion of the City, the Kosutka area to the North and the Bory area in the South, the train station and associated maintenance facilities, the brewery, and the Bory industrial facility.

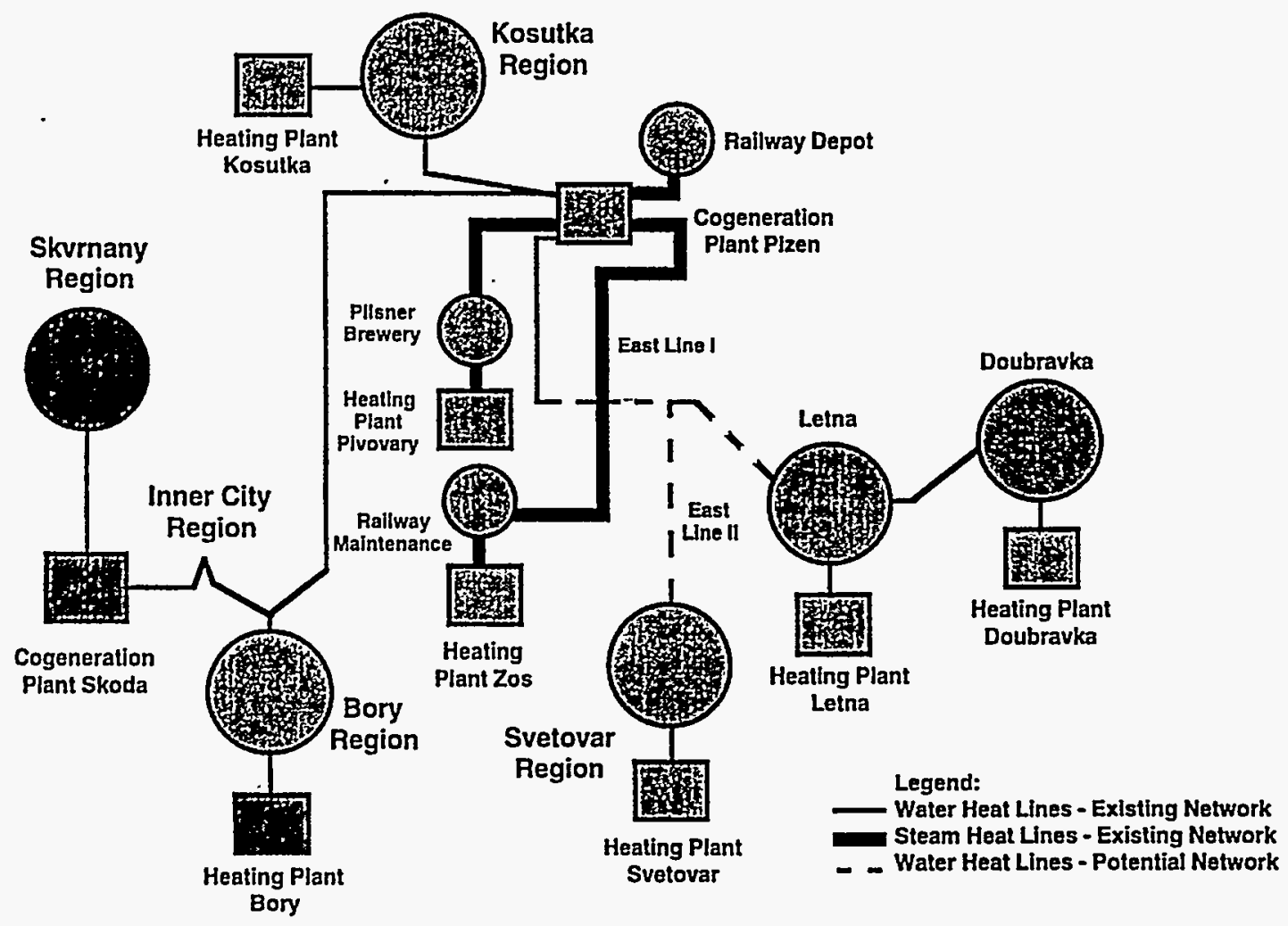

Figure 1. Plzen̆ District Heating System Schematic 
The Central and Kosutka regions consume hot water provided by the Plzen coal-fired cogeneration plant, supplemented by the Kosutka peaking plant. The Kosutka plant is being converted from coal to natural gas. The Plzen̆ cogeneration and Kosutka plants were formerly owned and operated by ZCE, West Bohemia Electric Utility, and are now $80 \%$ owned by the City, with the remainder scheduled for transfer to private ownership. The Central plan has a combined hot water and steam generating capacity of about $225 \mathrm{MW}_{\mathrm{t}}$, and the Kosutka plant has hot water generating capacity of about $17 \mathrm{MW}_{\mathrm{t}}$.

The Bory region to the South consumes hot water provided by the Bory plant, supplemented by hot water from the Plzeñ plant to meet peak needs. Modification of the hot water network will be necessary for the Plzen plant to provide sufficient quantities of hot water when the Bory hot water boilers are retired. The Bory plant is owned and operated by TEZA, the municipal district heating company and has a combined hot water and steam generating capacity of about $55 \mathrm{MW}_{\mathrm{t}}$.

The Bory industrial facility is served entirely by the Bory plant for steam needs and supplemented by the Plzeñ plant for peak hot water needs.

Steam for the train station is provided by the Plzen cogeneration plant. Steam for the train maintenance facilities is provided by the Zos plant in the summer months and supplemented by the Plzeñ plant in the winter months.

Steam for the brewery is provided by the Pivovary plant in the summer months and supplemented by the Plzeñ plant in the winter months.

The Letna/Doubravka Segment of the system is supplied by the Letna and Doubravka hot water plants, which consist of 8 coal-fired boilers and 1 oil-fired peaking boiler; these units are owned and operated by TEZA. These plants have hot water generating capacity of about $56 \mathrm{MW}_{\mathrm{t}}$ and supply buildings located in the Letna and Doubravka areas. TEZA also owns and operates the associated transmission and distribution system. The East I transmission line connecting the Plzen plant to the Letna/Doubravka areas is under construction and planned for completion in 1997.

The Svetovar Segment of the system is supplied by the Svetovar hot water plant, which consists of 4 coal-fired boilers; this plant is owned and operated by TEZA. This plant has hot water generating capacity of about $23 \mathrm{MW}_{\mathrm{t}}$ and supplies buildings located in the Svetovar area. TEZA also owns and operates the associated transmission and distribution system. This plant is in need of upgrade or replacement or connection to the Plzeň system; proposals to connect the Svetovar region to the Plzen system have been made, but no firm plans to do so have developed. This potential connection is referred to as the East II transmission line.

The Skoda/Skvrnany Segment of the system is supplied by the Skoda cogeneration plant, which consists of 3 coal-fired boilers and 2 oil-fired boilers that produce steam; these are owned and operated by Skoda Industries. This plant has combined hot water and steam capacity of about $323 \mathrm{MW}$ and provides steam and hot water to the Skoda industrial facilities and hot water to buildings in the Skvrnany area. Skoda Industries owns and operates the transmission and distribution system for its own uses. Skoda also owns and operates the transmission lines to the Skvrnany and Bory areas; TEZA owns and operates the associated distribution systems. TEZA also owns and operates a transmission line that interconnects the Plzen plant to the Western segment; although this interconnection exists, it is not used. 
The integrated assessment scope included examining alternative efficiency and supply resource options for the Central (central cogeneration and Kosutka plants), Letna/Doubravka, and Svetovar segments. These options were characterized by amount of capital investment, cost to consumers, and emissions reduction. It was assumed that the Skoda plant would continue to operate and provide heat to the Skvrnany customers at a price consistent with that charged other customers. 



\subsection{System Loads}

The hot water and steam loads for the system segments were developed in terms of peak thermal capacity (MW) in order to relate to supply capacity requirements for four load growth scenarios. The four scenarios were high and low growth with no-efficiency and high and.low growth with programmatic efficiency in the buildings sector. The no-efficiency case includes metering and controls at the heat exchanger stations and/or building boundary. Although the controls do reduce energy use by about $10 \%$, the scenarios are termed no-efficiency because the metering and controls are required by regulation. The programmatic efficiency scenarios reflect customer side efficiency improvements in the buildings sector obtained through an acquisition program.

The load growth scenarios for the three system segments are provided in Table 1.

Table 1. Hot Water and Steam Load Growth Scenarios by Peak Capacity (MW), 1992-1997, 2000 and 2010

\begin{tabular}{|c|c|c|c|c|c|c|c|c|c|}
\hline Scenario/Segment & 1992 & 1993 & 1994 & 1995 & 1996 & 1997 & 2000 & 2010 & $\begin{array}{l}\text { Growth } \\
(\% / v r) \\
\end{array}$ \\
\hline \multicolumn{10}{|c|}{ High Growth, No-Efficiency } \\
\hline Central Segment & 207 & 210 & 223 & 234 & 238 & 241 & 243 & 238 & 0.8 \\
\hline Letna/Doubravka & 47 & 47 & 47 & 47 & 56 & 58 & 60 & 58 & 1.2 \\
\hline Svetovar & 23 & 23 & 23 & 23 & 23 & 25 & 26 & 24 & 0.2 \\
\hline Total Hot Water & 277 & 280 & 293 & 304 & 317 & 324 & 329 & 320 & 0.8 \\
\hline Total Steam & 93 & 92 & 92 & 91 & 100 & 100 & 100 & 100 & 0.4 \\
\hline \multicolumn{10}{|c|}{ High Growth, With Efficiency } \\
\hline Central Segment & 207 & 210 & 222 & 232 & 232 & 233 & 228 & 212 & 0.1 \\
\hline Letna/Doubravka & 47 & 47 & 47 & 47 & 55 & 56 & 56 & 52 & 0.6 \\
\hline Svetovar & 23 & 23 & 23 & 23 & 23 & 24 & 24 & 22 & -0.3 \\
\hline Total Hot Water & 277 & 280 & 292 & 302 & 310 & 313 & 308 & 286 & 0.2 \\
\hline Total Steam & 93 & 92 & 92 & 91 & 100 & 100 & 100 & 100 & 0.4 \\
\hline \multicolumn{10}{|c|}{ Low Growth, No-Efficiency } \\
\hline Central Segment & 207 & 209 & 213 & 219 & 221 & 222 & 217 & 206 & 0.0 \\
\hline Letna/Doubravka & 47 & 47 & 47 & 47 & 50 & 52 & 52 & 51 & 0.5 \\
\hline Svetovar & 23 & 23 & 23 & 23 & 23 & 23 & 22 & 21 & -0.5 \\
\hline Total Hot Water & 277 & 279 & 283 & 289 & 294 & 297 & 291 & 278 & 0.0 \\
\hline Total Steam & 93 & 92 & 92 & 91 & 91 & 89 & 89 & 89 & -0.3 \\
\hline \multicolumn{10}{|c|}{ Low Growth, With Efficiency } \\
\hline Central Segment & 207 & 209 & 212 & 217 & 216 & 215 & 203 & 188 & -0.5 \\
\hline Letna/Doubravka & 47 & 47 & 47 & 47 & 50 & 51 & 49 & 46 & -0.1 \\
\hline Svetovar & 23 & 23 & 23 & 23 & 23 & 22 & 21 & 19 & -1.1 \\
\hline Total & 277 & 279 & 212 & 287 & 289 & 288 & 273 & 253 & -0.5 \\
\hline Total Steam & 93 & 92 & 92 & 91 & 91 & 89 & 89 & 89 & -0.3 \\
\hline
\end{tabular}


Components of the load growth are the existing customer base, new construction/customers, and connection of local boilers. Additional data showing the load growth by component is provided in Appendix A.

A major issue is the potential for retiring coal-fired local boilers, which are a major source of emissions, and either connecting the customers served by these boilers to the district heating system or encouraging conversion to natural gas. There are approximately 590 local boilers representing about $300 \mathrm{MW}_{\mathrm{t}}$ of capacity, of which 230 are coal-fired with about $130 \mathrm{MW}$, capacity. Of these, 20 have committed to connect to the district system. Economics indicate another 33 have the potential and may do so; these represent about $50 \mathrm{MW}_{\mathrm{t}}$ of capacity in the high load growth scenarios. The remaining 177 may have to pay the emissions penalty to continue operation, upgrade to cleaner burning coal technologies, or switch to other fuel types, which may include district heat. Additional analysis is needed to identify the economics, as well as policies and incentive programs to support these decisions. 


\section{0 . Baseline Emissions}

This section provides the estimated emissions by existing heat generation sources within the City of Plzen. The estimates provided in Table 2 show the reductions that are expected to result by upgrading the existing district heating equipment to comply with the 1997 emissions regulations and by connecting the number of distributed boilers to the district heating system as discussed in the prior section. The emissions upgrades examined were to fuel switch to higher quality black coal and to install baghouses for particulate removal.

Expected changes in emissions levels for compliance with the 1997 regulations are

- In all cases, the quantities of emissions from home furnaces remain unchanged, as this equipment is not subject to emissions regulations. As a result, the share of total emissions for home heating equipment remains constant or increases.

- The quantity of total particulates decreases by about $30 \%$. Particulates from district heat sources decrease from over 600 to over 230 tonnes and from 680 to 532 tonnes from local boiler sources.

- Sulfur dioxide emissions decrease by about $55 \%$ with reductions of 10,382 to 4345 tonnes from district heat sources and 540 to 421 tonnes from local boilers.

- Emissions of nitrous oxides increase by $4 \%$. In the case of district heat sources, these emissions increase from 2443 to 2599 tonnes and decrease from 178 to 139 tonnes from local boiler sources.

- Carbon monoxide emissions decrease by $1 \%$ with an increase from 153 to 217 tonnes from district heat sources and a decrease from 400 to 312 tonnes from local boilers.

The total emissions for 1997 will serve as the baseline for comparing supply alternatives, as these represent compliance with upcoming emissions regulations for the existing supply resources.

Table 2. Emissions from Existing Generating Supply Resources (Tonnes/year), 1993 and Compliance with 1997 Regulations

\begin{tabular}{||r|r|r|r|r|r|r|r|r||}
\hline & \multicolumn{4}{|c|}{1993} & \multicolumn{4}{|c|}{1997} \\
\hline \multicolumn{1}{|c|}{ Sources } & Particulates & \multicolumn{1}{c|}{$\mathrm{SO}_{2}$} & \multicolumn{1}{c|}{$\mathrm{NO}_{\mathrm{x}}$} & $\mathrm{CO}$ & Particulates & $\mathrm{SO}_{2}$ & $\mathrm{NO}_{\mathrm{x}}$ & \multicolumn{1}{c|}{$\mathrm{CO}$} \\
\hline \hline $\begin{array}{l}\text { Existing District } \\
\text { Heat Plants, } \\
\text { Including Soda }\end{array}$ & & & & & & & & \\
\hline Local Boilers & $37 \%$ & $92 \%$ & $87 \%$ & $6 \%$ & $21 \%$ & $85 \%$ & $89 \%$ & $8 \%$ \\
\hline Home Furnaces & $21 \%$ & $5 \%$ & $6 \%$ & $14 \%$ & $47 \%$ & $8 \%$ & $5 \%$ & $11 \%$ \\
\hline Tonnes & 1658 & 11,297 & 2,799 & 2,782 & 1,136 & 5,140 & 2,916 & 2,759 \\
\hline \hline
\end{tabular}





\subsection{Supply Resources}

The assessment of supply resources examined four alternatives to upgrade the Plzen central heating plant. All options assume that new and existing units will comply with 1997 emissions regulations. The major distinguishing characteristics (fuel type, size, and date of introduction) of the Central Plant capacity configurations to meet the high load are

Coal 1997 Addition of new coal-fired cogeneration capacity in 1997 with maximum thermal output of $75 \mathrm{MW}_{\mathrm{t}}$ and electrical output of $32 \mathrm{MW}_{\mathrm{c}}$.

Coal 2003 Addition of new $75 \mathrm{MW}$, coal-fired cogeneration capacity in 2005 with maximum output of $75 \mathrm{MW}_{\mathrm{\imath}}$ and $32 \mathrm{MW}_{\mathrm{c}}$.

$65 \mathrm{MW}$ Gas Addition of new natural gas-fired cogeneration capacity in 1997 with maximum output of $65 \mathrm{MW}_{\mathrm{t}}$ and $89 \mathrm{MW}_{\mathrm{e}}$.

$60 \mathrm{MW}$ Gas Addition of new natural gas-fired cogeneration capacity in 1997 with maximum output of $60 \mathrm{MW}_{\mathrm{t}}$ and $73 \mathrm{MW}_{\mathrm{e}}$.

- The capacity configurations were downsized to meet the low load growth scenarios.

Available peak capacity for each of the Plzeñ central heating plant configurations is shown in Table 3.

Additional information describing the make-up of each capacity configuration is provided in Appendix B.

Table 3. Peak Capacity (MW) for Plzeñ Central Heating Plant Configuration, 1993-2000, 2005 and 2010

\begin{tabular}{|c|c|c|c|c|c|c|c|c|}
\hline Configuration & 1993 & 1994 & 1995 & 1996 & 1997 & 2000 & 2005 & 2010 \\
\hline \multicolumn{9}{|c|}{ High Load Growth } \\
\hline Coal 1997 & 305 & 305 & 305 & 384 & 380 & 380 & 391 & 391 \\
\hline Coal 2003 & 305 & 305 & 305 & 384 & 384 & 384 & 390 & 390 \\
\hline $65 \mathrm{MW}$ Gas & 305 & 305 & 304 & 384 & 369 & 369 & 380 & 380 \\
\hline $60 \mathrm{MW}$ Gas & 305 & 305 & 305 & 384 & 353 & 353 & 364 & .364 \\
\hline \multicolumn{9}{|l|}{ Low Load Growth } \\
\hline Coal 1997 & 305 & 305 & 305 & 384 & 380 & 380 & 333 & 333 \\
\hline Coal 2003 & 305 & 305 & 305 & 384 & 384 & 384 & 352 & 352 \\
\hline $65 \mathrm{MW}$ Gas & 305 & 305 & 305 & 384 & 369 & 369 & 322 & 322 \\
\hline $60 \mathrm{MW}$ Gas & 305 & 305 & 305 & 384 & 353 & 353 & 306 & 306 \\
\hline
\end{tabular}





\subsection{Efficiency Resource}

The efficiency resource assessment developed estimates of the space and water heat energy efficiency potential in the residential and non-residential buildings sectors; limited information was collected on efficiency potential in the industrial sector. The buildings sector is estimated to account for about $60 \%$ of space and water heat energy use, with the industrial sector accounting for the balance. District heat is estimated to provide $56 \%$ of buildings sector heat and hot water energy use and $81 \%$ of industrial sector steam and hot water requirements.

Fifty measures were considered for reducing the buildings sector space and water heat consumption, of which the following 14 were determined to be cost-effective because they have a positive net present value (note: not all measures were applied to each of the 18 building types considered).

- Insulate building exterior side walls

- Weatherstrip elevator penthouse, stairway, doors and windows

- Weatherstrip windows and doors

- Install revolving or double door in vestibule

- Install storm windows

- Install zone valves on each radiator and install central thermostats with 'on time counter' in each apartment

- Install heat recovery vent system in basements

- Install heat reflectors behind each radiator or heater

- Remove draperies from radiator

- Install low-flow shower heads

- Install flow restrictors on faucets

- Insulate hot water pipes in unconditioned spaces

- Install hot water flow meters

- Install waste water heat recovery heat exchanger.

The efficiency assessment estimated a $40 \%$ reduction in buildings sector energy consumption at a levelized cost of $105 \mathrm{Kc} / \mathrm{GJ}$. This amount was adjusted downward to provide for a $15 \%$ reduction in buildings sector energy consumption and $10 \%$ reduction in heat production for three reasons. First, experience in the U.S. has shown that engineering-based estimates, such as the one for Plzen, typically predict greater potential than is realized and that the over-prediction can be as high as 2:1. Second, the 
efficiency assessment included all measures and the baseline includes the effect of metering and controls at the heat exchanger station or building boundary; these controls are estimated to reduce consumption by about $10 \%$ as noted in the system loads discussion. Third, experience in a demonstration of buildings sector energy efficiency in Krakow, Poland, for the types of measures considered indicates that a reduction of about $25 \%$ can be achieved, of which $10 \%$ is from controls at the heat exchanger station or building boundary.

The installed cost of the measures considered is estimated to be $5700 \mathrm{Kc} / \mathrm{GJ}$ for first year savings. This cost appears consistent with the costs experienced in the Krakow demonstration and with derating the efficiency potential, while keeping costs constant. These adjustments are felt to present $a$ conservative picture for the buildings sector efficiency resource.

Industrial sector energy efficiency potential is reported to be on the order of $15 \%$ to $20 \%$ of base use. This estimate is based upon the findings of other studies and discussions with facility managers. The cost of acquiring this resource was not available. 


\subsection{Integrated Findings}

This section provides the integration of the efficiency and supply resources to meet the high and low load and growth scenarios.

Moderate System Expansion. The loads on the Central System increase with the completion of Heat Line East I to include the Letna/Doubravka areas with service provided by the Plzeñ Central Plant per the four capacity configurations presented in the supply discussion above. The loads are subject to high and low growth, with and without programmatic efficiency. This case considered life extension to the existing Svetovar plant and continued operation of this segment as a standalone system. The Supply Assessment examined three alternatives for the Svetovar heat generation plant-life extension and environmental compliance, conversion to natural gas, and replacement with a micro-cogeneration unit. Life extension was found to be the most cost-effective alternative; therefore, the other two alternatives were not considered in this integrated assessment. Within the moderate system expansion case, the Coal 2003 high load without efficiency scenario is considered the base case, and it most closely reflects the simple life extension case.

Full System Expansion. The loads on the Central System increase with the completion of Heat Lines East I and II to include the Letna/Doubravka and Svetovar areas with service provided by the Plzen Central Plant per the four capacity configurations presented in the supply discussion above. The loads are subject to high and low growth, with and without programmatic efficiency. In this case, the Svetovar plant is retired.

The first step in integrating the efficiency and supply assessments was to identify cases where supply resources were not adequate to meet the projected loads and not consider these cases further. This step compared the peak loads with the corresponding supply capacities, considering an outage of the largest generating unit. This comparison showed significant capacity shortfalls for all supply configurations under the full system expansion case with high load growth and without programmatic efficiency. As a result, these cases were not considered further in the integration. The process and findings for load/capacity surplus/deficit comparison are contained in Appendix C.

The next step characterized the economic and environmental attributes of the cases considered. Economic attributes include the capital cost to implement the supply and efficiency resources, the levelized cost in $\mathrm{Kc} / \mathrm{GJ}$ for the combined production of heat and steam, the typical residential energy bill, and the levels of emissions (particulates, $\mathrm{SO}_{2}, \mathrm{NO}_{\mathrm{x}}$, and $\mathrm{CO}$ ). The levelized cost was developed on a cash flow basis for the period 1994-2000. The attributes for the moderate system expansion case without and with efficiency are presented in Table 4.

In all cases, the Coal 2003 supply configuration requires the least capital investment, particularly in the $1993-2000$ period at a cost of $40 \%$ of the next most expensive supply configuration. In the longer term, the differential in capital cost is on the order of $25 \%$. 
Table 4. Economic and Environmental Attributes for Moderate System Load Expansion by Plant Configuration, High and Low Load Growth Without and With Efficiency

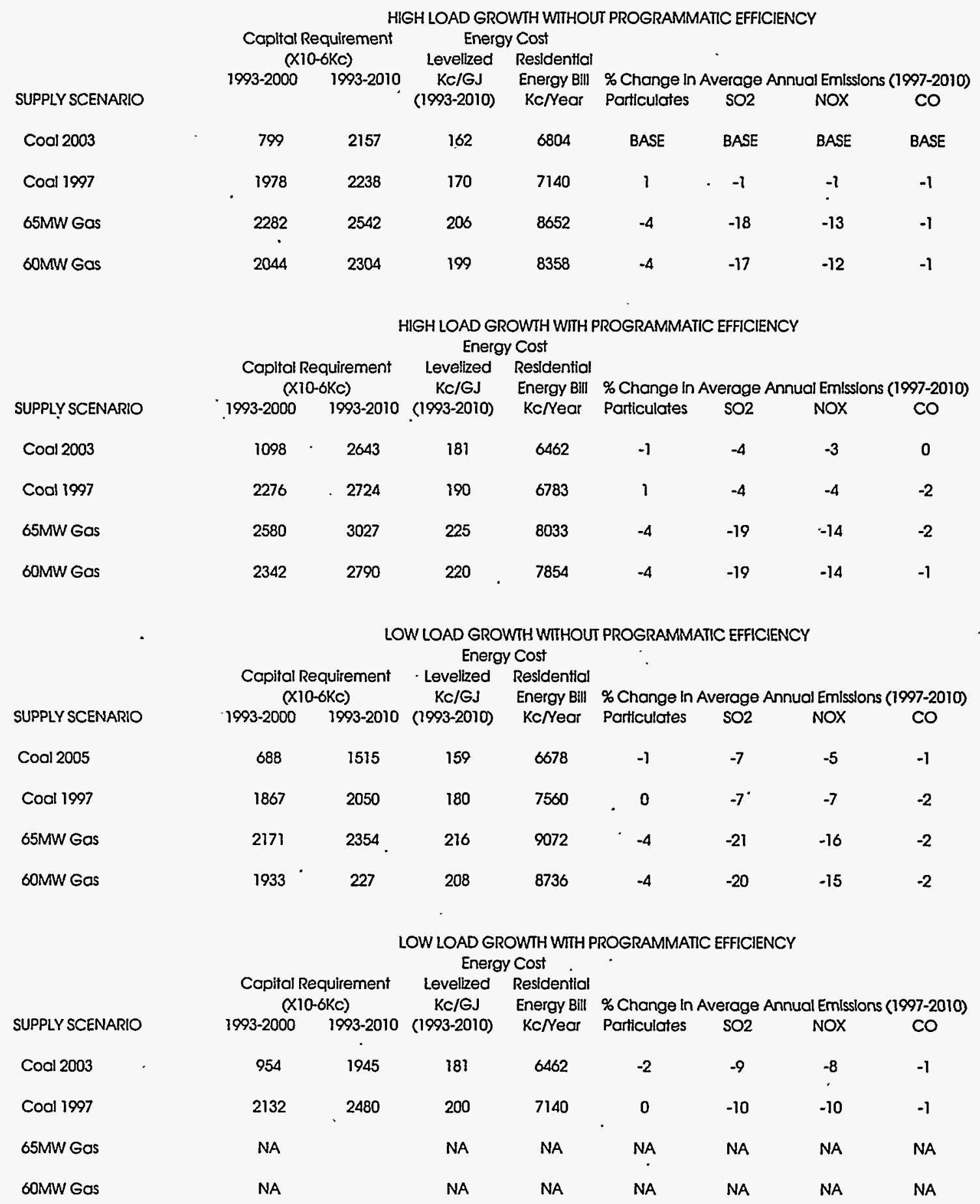


The levelized energy cost for the period 1994-2010 reflects the combined effect of the differential in capital, fuel, and other operations and maintenance costs. In the two high growth scenarios, the two coal configurations can be considered nearly equal and about $20 \%$ below the cost of the two gas-fired configurations. In the two low growth scenarios, the Coal 2003 option is about $10 \%$ less than the Coal 1997 option and about $20 \%$ less than the gas-fired options. Note that the levelized energy cost includes the Svetovar life extension, which reduces the price per GJ for the balance of the system by about $8 \mathrm{Kc}$. While the levelized energy cost increases about $10 \%$ in the efficiency scenario, the typical residential energy bill based on average consumption of $42 \mathrm{GJ} / \mathrm{year}$ is expected to decrease about $5 \%$.

The reductions in emissions are based upon total emissions from heat generation sources in the City of Plzen. The two gas-fired options clearly provide the greatest reduction in emissions and efficiency provides modest additional benefit over the without-efficiency case.

Table 5 provides the attribute data for the full system expansion case without and with efficiency. As noted above, the four supply options were not considered for the high load without efficiency scenario because of the deficit in supply capacity to meet the loads.

The relationships in this table are similar to those for the moderate system expansion case. The capital requirements for the coal options are less than the gas-fired options, particularly for the Coal 2003 option. The difference in the levelized energy cost narrows slightly between the coal and gas options and stays about the same between the two coal options. Emissions also show a reduction with the implementation of efficiency.

A comparison of the full system expansion to the moderate system shows the capital requirements to be about $2 \%$ higher and the levelized energy cost to be about $2 \%$ to $5 \%$ higher. Although the utilization of the central system capacity increases with the full system expansion, the production cost is still higher than that of the Svetovar plant (about $150-170 \mathrm{Kc} / \mathrm{GJ}$ ). ${ }^{\text {(a) }}$ As a result, the typical energy bill increases over that in the moderate system expansion case.

Emissions are estimated to increase slightly from the moderate system expansion case. The models predict that emissions associated with the increased utilization of the Central Plant more than offset the reductions achieved from not extending the life of the Svetovar Plant. While this is not intuitively obvious, the other basic relationships still hold-the gas-fired options provide significant emissions reductions for sulfur and nitrous oxides, and efficiency provides a modest additional reduction over the without efficiency scenario.

(a) The supply assessment projected a levelized energy cost for the Svetovar segment of approximately $350 \mathrm{Kc} / \mathrm{GJ}$ and a current cost of about $250 \mathrm{Kc} / \mathrm{GJ}$, whereas the City claims the current production cost is about $125 \mathrm{Kc} / \mathrm{GJ}$. The latter cost was escalated at a $3 \%$ real rate to provide a levelized cost of about $150 \mathrm{Kc} / \mathrm{GJ}$, which was used in the results reported above. Had the higher cost been used, the Svetovar connection would have been economically attractive. 
Table 5. Economic and Environmental Attributes for Full System Load Expansion by Central Plant Configuration, High and Low Load Growth Without and With Efficiency

\begin{tabular}{|c|c|c|c|c|c|c|c|c|}
\hline \multirow[b]{4}{*}{ SUPPLY SCENARJO } & \multicolumn{8}{|c|}{ HIGH LOAD GROWTH WITH PROGRAMMATIC EFFICIENCY } \\
\hline & \multirow{2}{*}{\multicolumn{2}{|c|}{$\begin{array}{l}\text { Capltal Requirement } \\
(\alpha 10-6 \mathrm{KC})\end{array}$}} & Levelized & Residential & \multirow{2}{*}{\multicolumn{4}{|c|}{ \% Change in Average Annual Emlssions (1997-2010) }} \\
\hline & & & KC/GJ & Energy Bill & & & & \\
\hline & $1993-2000$ & $1993-2010$ & $(1993-2010)$ & $\mathrm{Kc} / \mathrm{Year}$ & Particulates & $\mathrm{SO} 2$ & NOX & CO \\
\hline Coal 2003 & 1136 & 2699 & 185 & 6605 & 0 & 0 & $\mathbf{0}$ & 0 \\
\hline Coal 1997 & 2315 & 2780 & 194 & 6926 & 1 & -1 & -2 & -2 \\
\hline $65 \mathrm{MW}$ Gas & 2619 & 3084 & 231 & 8247 & -4 & -18 & -14 & -1 \\
\hline \multirow[t]{3}{*}{ 60MW Gas } & 2381 & 2846 & 225 & 8033 & -4 & -17 & -14 & -1 \\
\hline & \multicolumn{8}{|c|}{$\begin{array}{l}\text { LOW LOAD GROWTH WITHOUT PROGRAMMATIC EFFICIENCY } \\
\text { Energy Cost }\end{array}$} \\
\hline & \multicolumn{2}{|c|}{$\begin{array}{c}\text { Caplial Requirement } \\
\text { (X10-6KC) }\end{array}$} & $\begin{array}{l}\text { Levelized } \\
\text { Kc/GJ }\end{array}$ & $\begin{array}{l}\text { Residential } \\
\text { Energy Bill }\end{array}$ & \multicolumn{4}{|c|}{$\%$ Change in Average Annual Emisslons (1997-2010) } \\
\hline SUPPLY SCENARIO & $1993-2000$ & $1993-2010$ & $(1993-2010)$ & Kc/rear & Particulates & $\mathrm{SO} 2$ & NOX & co \\
\hline Coal 2003 & 731 & 1557 & 168 & 7056 & -1 & -4 & -5 & -1 \\
\hline CoOl 1997 & 2020 & 2280 & 187 & 7854 & 1 & -4 & -6 & -2 \\
\hline $65 \mathrm{MW}$ Gas & 2324 & 2584 & 224 & 9408 & -4 & -19 & -16 & -2 \\
\hline \multirow[t]{3}{*}{ 60MW Gas } & 2086 & 2346 & 219 & 9198 & -4 & -19 & -15 & -2 \\
\hline & \multicolumn{8}{|c|}{$\begin{array}{l}\text { LOW LOAD GROWIH WITH PROGRAN } \\
\text { Energy COSt }\end{array}$} \\
\hline & \multicolumn{2}{|c|}{$\begin{array}{l}\text { Copital Requirement } \\
\text { (XI0-6Kc) }\end{array}$} & $K C / G J$ & Energy Bill & \multirow{2}{*}{\multicolumn{4}{|c|}{$\begin{array}{l}\text { \% Change in Average Annual Emissions (1997-2010) } \\
\text { Particulates SO2 NOX CO C C }\end{array}$}} \\
\hline SUPPLY SCENARIO & 1993-2000 & 1993-2010 & $(1993-2010)$ & Kc/Year & & & & \\
\hline Cool 2003 & 991 & 1995 & 178 & 6355 & -1 & -7 & -5 & -1 \\
\hline Cool 1997 & 2169 & 2530 & 205 & 7319 & 0 & -7 & -9 & -2 \\
\hline 65MW Gas & 2473 & 2834 & 244 & 8711 & -4 & -21 & -17 & -2 \\
\hline 60MW Gas & 2235 & 2596 & 236 & 8425 & -4 & -20 & -17 & -2 \\
\hline
\end{tabular}


The integration of the supply and efficiency assessments did not optimize the amount and timing of the addition of the efficiency and supply resources; had this been done, it is expected that the costs (capital and levelized) and emissions would be somewhat lower. However, it is not likely that optimizing the resources would change the relationships evidenced in the integration among the resource options considered-life extension to the existing system, early coal upgrade, or heavier reliance on natural gas with an early upgrade. 



\subsection{Related Publications}

- This report is one of four containing an energy assessment of options for upgrading the district heating system for the City of Plzen̆, Czech Republic:

An Evaluation of the Supply-Side Options for the Plzeñ District Heating System (Gilbert/Commonwealth)

Assessment of the Buildings Sector Efficiency Resource for the City of Plzeñ (Pacific Northwest National Laboratory)

Efficiency and Supply Resource Options for the Upgrade of the Plzen District Heating System (Pacific Northwest National Laboratory)

Heat Supply in Plzeñ: Final Report (SEVEn, Pacific Northwest National Laboratory)

All of these reports were published by

Pacific Northwest National Laboratory

901 D Street S.W., Suite 900

Washington, DC 20024-2115. 
Appendix A

System Loads 


\section{Appendix A}

\section{System Loads}

Tables A.1 through A.4 provide the load projections associated with the system segments for the four growth scenarios: high demand without efficiency; high demand with efficiency; low demand without efficiency; and low demand with efficiency. Within each segment, the loads are shown by area of contribution-existing customers connected to the system, customers currently served by boilers that have either promised to or have indicated they will connect to the system, and new construction.

As noted in the system loads section, the no-efficiency scenarios reflect about a $10 \%$ reduction due to the pending installation of metering and controls required by regulation. This equipment will be installed at heat exchanger stations and/or the building boundary. The programmatic efficiency scenarios reflect an additional $10 \%$ reduction that is obtained through customer-side efficiency improvements. These improvements reflect combinations of weatherization, insulation, radiator controls, and heat exchangers.

Tables A.5 and A.6 provide the load projections for the system configurations examined. The moderate system expansion case comprises the combined load from the Central, Kosutka, and Letna/Doubravka areas. The full system expansion case further includes the Svetovar segment. 
Table A.1. High Demand Without Programmatic Efficiency

Hot Water

$\begin{array}{lllllllll}1992 & 1993 & 1994 & 1995 & 1996 & 1997 & 2000 & 2005 & 2010^{*}\end{array}$

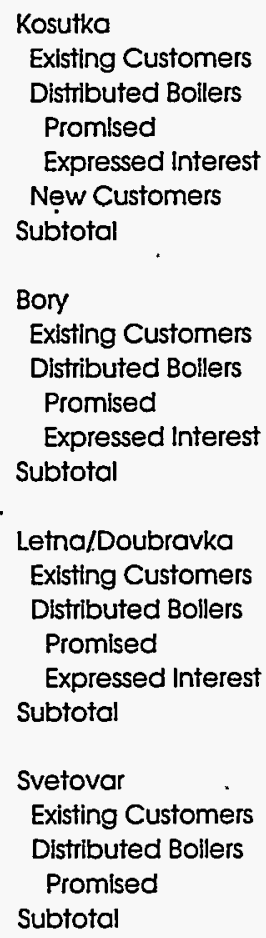

Steam

Notes:

Source Data is Gilbert/Commonwealth Report, Appendlx E, Table A.l.

Regulations requiring system side metering and controls are assumed to provide a $10 \%$ efficlency improvement in the existing customer base between 1996 and 2005.

New customer data reflects efficiency improvement resulting from regulated metering and controls. 
Table A.2. High Demand With Programmatic Efficiency

\begin{tabular}{|c|c|c|c|c|c|c|c|c|c|}
\hline \multicolumn{9}{|l|}{ Hot Water } & 2010 \\
\hline \multicolumn{10}{|l|}{ Kosutka } \\
\hline Existing Customers & 133.0 & 133.0 & 133.0 & 133.0 & 130.3 & 127.7 & 119.7 & 106.4 & 106.4 \\
\hline Distributed Boilers & & & & & & . & & & \\
\hline Promised & & & 0.5 & 0.6 & 0.6 & 2.3 & 2.3 & 2.3 & 2.3 \\
\hline Expressed Interest & & & & 4.0 & 4.0 & 4.0 & 4.0 & 4.0 & 4.0 \\
\hline Now Customers & & & & 1.7 & 2.6 & 3.6 & 11.3 & 13.6 & 15.4 \\
\hline Subtotal & 133.0 & 1333.0 & 133.5 & 139.3 & 137.5 & 137.5 & 137.2 & 126.2 & 128.0 \\
\hline \multicolumn{10}{|l|}{ Bory } \\
\hline $\begin{array}{l}\text { Existing Customers } \\
\text { Distrlbuted Bollers }\end{array}$ & 74.0 & 74.0 & 74.0 & 74.0 & 72.5 & 71.0 & 66.6 & 59.2 & 59.2 \\
\hline Promised & & 2.7 & 11.5 & 13.3 & 15.0 & 16.0 & 16.0 & 16.0 & 16.0 \\
\hline Expressed interest & & & 2.6 & 4.9 & 7.0 & 8.6 & 8.6 & 8.6 & 8.6 \\
\hline Subtotal & 74.0 & 76.7 & 88.1 & 92.2 & 94.6 & 95.6 & 91.2 & 83.8 & 83.8 \\
\hline \multicolumn{10}{|l|}{ Letna/Doubravka } \\
\hline $\begin{array}{l}\text { Existing Customers } \\
\text { Dlstributed Bollers }\end{array}$ & 46.5 & 46.5 & 46.5 & 46.5 & 45.6 & 44.6 & 41.9 & 37.2 & 37.2 \\
\hline Promlsed & & & & & 5.0 & 6.4 & 6.4 & 6.4 & 6.4 \\
\hline Expressed Interest & & & & & $4.1^{\circ}$ & 4.6 & 7.9 & 7.9 & 7.9 \\
\hline Subtotal & 46.5 & 46.5 & 46.5 & 46.5 & 54.7 & 55.6 & 56.2 & 51.5 & 51.5 \\
\hline \multicolumn{10}{|l|}{ Svetovar } \\
\hline $\begin{array}{l}\text { Existing Customers } \\
\text { Distributed Bollers }\end{array}$ & 23.2 & 23.2 & 23.2 & 23.2 & 22.7 & 22.3 & 20.9 & 18.6 & 18.6 \\
\hline Promlsed & & & & & & 1.8 & 3.2 & 3.2 & 3.2 \\
\hline Subtotal & 23.2 & 23.2 & 23.2 & 23.2 & 22.7 & 24.1 & 24.0 & 21.7 & 21.7 \\
\hline Steam & 93.0 & 92.3 & 91.7 & 91.1 & 99.8 & 100.0 & 100.0 & 99.6 & 99.6 \\
\hline \multicolumn{10}{|c|}{$\begin{array}{l}\text { Notes: } \\
\text { Source Data is Gllbert/Commonwealth Report, Appendix E, Table A.1. } \\
\text { Regulatlons requiring system side metering and controls are assumed to provide a } 10 \% \text { efficlency improvement } \\
\text { in the exlsting customer base between } 1996 \text { and } 2005 \text {. }\end{array}$} \\
\hline
\end{tabular}


Table A.3. Low Demand Without Programmatic Efficiency

Hot Water

$\begin{array}{lllllllll}1992 & 1993 & 1994 & 1995 & 1996 & 1997 & 2000 & 2005 & 2010\end{array}$

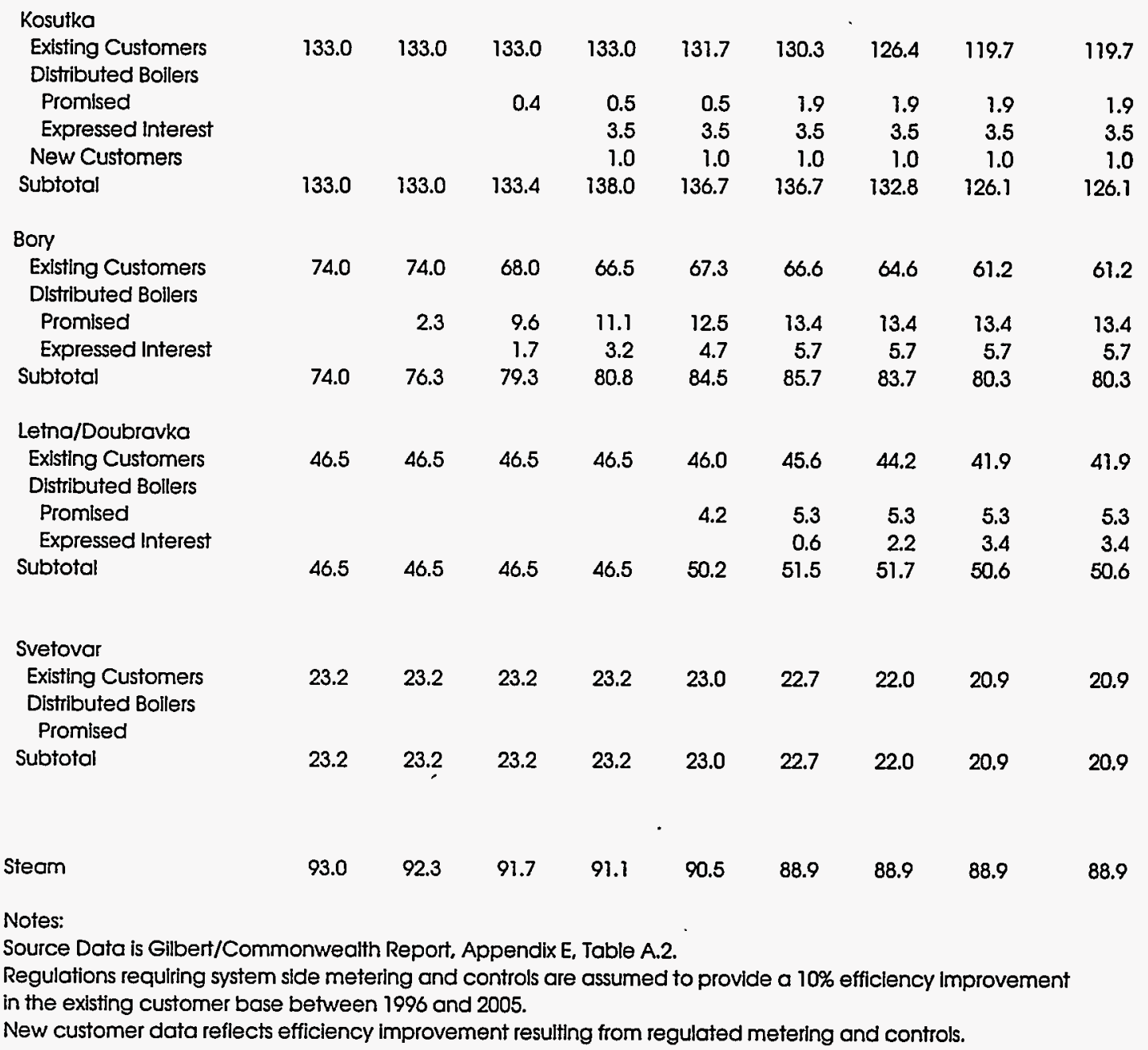


Table A.4. Low Demand With Programmatic Efficiency

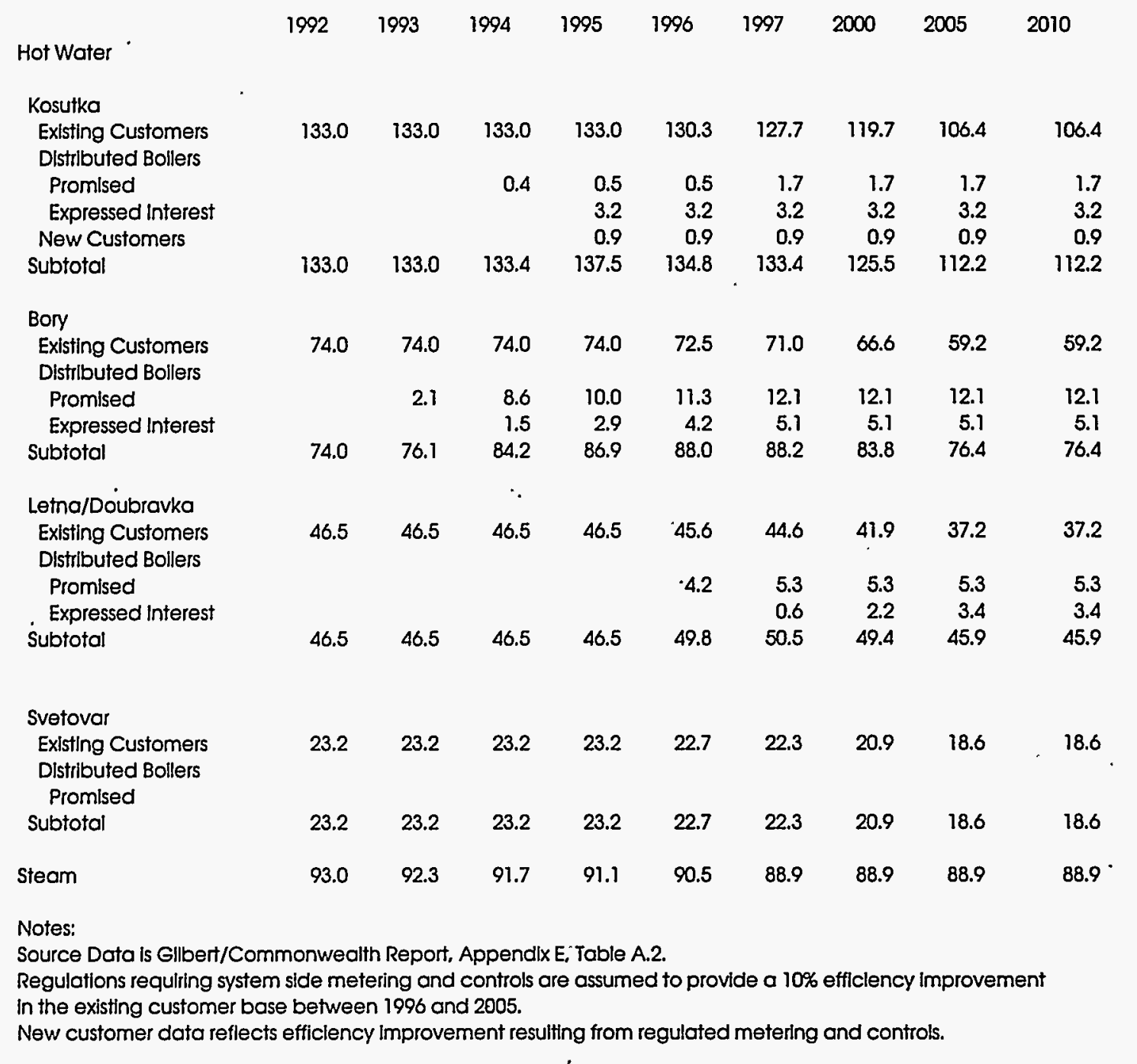


Table A.5. Moderate System Expansion (Kosutka, Bory, and Letna Doubravka)

Hot Water

Kosutka

Bory

Letna/Doubravka

Hot Water Total

Steam

199

High Demand Without Programmatic Efficlency

Hot Water

Kosutka

- Bory

Letna/Doubravka

Hot Water Total

Steam

$\begin{array}{rrrrrrrrr}133.0 & 133.0 & 133.5 & 140.0 & 139.7 & 141.2 & 145.8 & 141.7 & 143.7 \\ 74.0 & 77.0 & 89.7 & 94.2 & 97.8 & 99.8 & 97.6 & 93.9 & 93.9 \\ & & & & 56.1 & 57.8 & 60.1 & 57.8 & 57.8 \\ 207.0 & 210.0 & 223.2 & 234.2 & 293.6 & 298.8 & 303.4 & 293.4 & 295.4 \\ 93.0 & 92.3 & 91.7 & 91.1 & 99.8 & 100.0 & 100.0 & 99.6 & 99.6\end{array}$

High Demand With Programmatic Efflclency

$\begin{array}{rrrrrrrrr}133.0 & 133.0 & 133.5 & 139.3 & 137.5 & 137.5 & 137.2 & 126.2 & 128.0 \\ 74.0 & 76.7 & 88.1 & 92.2 & 94.6 & 95.6 & 91.2 & 83.8 & 83.8 \\ & & & & 54.7 & 55.6 & 56.2 & 51.5 & 51.5 \\ 207.0 & 209.7 & 221.6 & 231.5 & 286.8 & 288.7 & 284.5 & 261.5 & 263.3 \\ 93.0 & 92.3 & 91.7 & 91.1 & 99.8 & 100.0 & 100.0 & 99.6 & 99.6\end{array}$

Hot Water

Kosutka

Bory

Letna/Doubravko

Hot Water Total

Steam

Low Demand Without Programmatic Efficlency

$\begin{array}{rrrrrrrrr}133.0 & 133.0 & 133.4 & 138.0 & 136.7 & 136.7 & 132.8 & 126.1 & 126.1 \\ 74.0 & 76.3 & 79.3 & 80.8 & 84.5 & 85.7 & 83.7 & 80.3 & 80.3 \\ & & & & 50.2 & 51.5 & 51.7 & 50.6 & 50.6 \\ 207.0 & 209.3 & 212.7 & 218.8 & 271.4 & 274.0 & 268.1 & 257.0 & 257.0 . \\ 93.0 & 92.3 & 91.7 & 91.1 & 90.5 & 88.9 & 88.9 & 88.9 & 88.9\end{array}$

Hot Water

Kosutka

Bory

Letna/Doubravka

Hot Water Total

Low Demand With Programmatic Efflclency

Steam

$\begin{array}{rrrrrrrrr}133.0 & 133.0 & 133.4 & 137.5 & 134.8 & 133.4 & 125.5^{\circ} & 112.2 & 112.2 \\ 74.0 & 76.1 & 84.2 & 86.9 & 88.0 & 88.2 & 83.8 & 76.4 & 76.4 \\ & & & & 49.8 & 50.5 & 49.4 & 45.9 & 45.9 \\ 207.0 & 209.1 & 217.5 & 224.4 & 272.6 & 272.2 & 258.6 & 234.5 & 234.5 \\ 93.0 & 92.3 & 91.7 & 91.1 & 90.5 & 88.9 & 88.9 & 88.9 & 88.9\end{array}$

Note:

Assumes connection of Letna/Doubravka load in 1996 
Table A.6. Full System Expansion (Kosutka, Bory, Letna Doubravka, and Svetovar)

\begin{tabular}{|c|c|c|c|c|c|c|c|c|c|}
\hline & 1992 & 1993 & 1994 & 1995 & 1996 & 1997 & 2000 & 2005 & 2010 \\
\hline \multicolumn{10}{|c|}{ High Demand Without Programmatic Efficiency } \\
\hline Hot Woter & & & & & & & & & \\
\hline Kosutka & 133.0 & 133.0 & 133.5 & 140.0 & 139.7 & 141.2 & 145.8 & 141.7 & 143.7 \\
\hline Bory & 74.0 & 77.0 & 89.7 & 94.2 & 97.8 & 99.8 & 97.6 & 93.9 & 93.9 \\
\hline Letna/Doubravka & & & & & 56.1 & 57.8 & 60.1 & 57.8 & 57.8 \\
\hline Svetovar & & & & & & 24.7. & 25.5 & 24.4 & 24.4 \\
\hline Hot Water Total & 207.0 & 210.0 & 223.2 & 234.2 & 293.6 & 323.6 & 329.0 & 317.7 . & 319.7 \\
\hline Steam & 93.0 & 92.3 & 91.7 & 91.1 & 99.8 & 100.0 & 100.0 & 99.6 & 99.6 \\
\hline \multicolumn{10}{|c|}{ High Demand With Programmatic Efficlency } \\
\hline Hot Water & & & & & & & & & \\
\hline Kosutka & 133.0 & 133.0 & 133.5 & 139.3 & 137.5 & 137.5 & 137.2 & 126.2 & 128.0 \\
\hline Bory & 74.0 & 76.7 & 88.1 & 92.2 & 94.6 & 95.6 & 91.2 & 83.8 & 83.8 \\
\hline Letna/Doubravka & & & & & 54.7 & 55.6 & 56.2 & 51.5 & 51.5 \\
\hline Svetovar & & & & & & 24.1 & 24.0 & 21.7 & 21.7 \\
\hline Hot Water Total & 207.0 & 209.7 & 221.6 & 231.5 & 286.8 & 312.8 & 308.5 & 283.2 & 285.0 \\
\hline Steam & 93.0 & 92.3 & 91.7 & 91.1 & 99.8 & 100.0 & 100.0 & 99.6 & 99.6 \\
\hline \multicolumn{10}{|c|}{ Low Demand Without Programmatic Efflciency } \\
\hline Hot Water & & & & & & & & & \\
\hline Kosutka & 133.0 & 133.0 & 133.4 & 138.0 & 136.7 & 136.7 & 132.8 & 126.1 & 126.1 \\
\hline Bory & 74.0 & 76.3 & 79.3 & 80.8 & 84.5 & 85.7 & 83.7 & 80.3 & 80.3 \\
\hline Letna/Doubravka & & & & & 50.2 & 51.5 & 51.7 & 50.6 & 50.6 \\
\hline Svetovar & & & & & & 22.7 & 22.0 & 20.9 & 20.9 \\
\hline Hot Water Total & 207.0 & 209.3 & 212.7 & 218.8 & 271.4 & 296.7 & 290.2 & 277.8 & 277.8 \\
\hline Steam & 93.0 & 92.3 & 91.7 & 91.1 & 90.5 & 88.9 & 88.9 & 88.9 & 88.9 \\
\hline \multicolumn{10}{|c|}{ Low Demand With Programmatic Efficlency } \\
\hline Hot Water & & & & & & & & & \\
\hline Kosutka & 133.0 & 133.0 & 133.4 & 137.5 & 134.8 & 133.4 & 125.5 & 112.2 & 112.2 \\
\hline Bory & 74.0 & 76.1 & 84.2 & 86.9 & 88.0 & 88.2 & 83.8 & 76.4 & 76.4 \\
\hline Letna/Doubravka & & & & & 49.8 & 50.5 & 49.4 & 45.9 & 45.9 \\
\hline Svetovar & & & & & & 22.3 & 20.9 & 18.6 & 18.6 \\
\hline Hot Water Total & 207.0 & 209.1 & 217.5 & 224.4 & 272.6 & 294.5 & 279.5 & 253.0 & 253.0 \\
\hline Steam & 93.0 & 92.3 & 91.7 & 91.1 & 90.5 & 88.9 & 88.9 & 88.9 & 88.9 \\
\hline
\end{tabular}

Assumes connection of Letna/Doubravka load in 1996 and Svetovar load in 1997 
Appendix B

Supply Resources 


\section{Appendix B}

\section{Supply Resources}

Table B.1 provides summary information on the existing and alternative heat supply resources. The summary information provides the name, type of output (hot water or steam), number of units, capacity of each unit, year constructed, and action applicable to the alternative capacity configurations.

Tables B.2 through B.5 provide the combinations of generating capacities that were configured for the high and low load growth scenarios in the moderate system expansion case. These tables show the total capacity available and total capacity reduced by the largest unit to reflect a worst case outage. 
Table B.1. Supply Resource Description

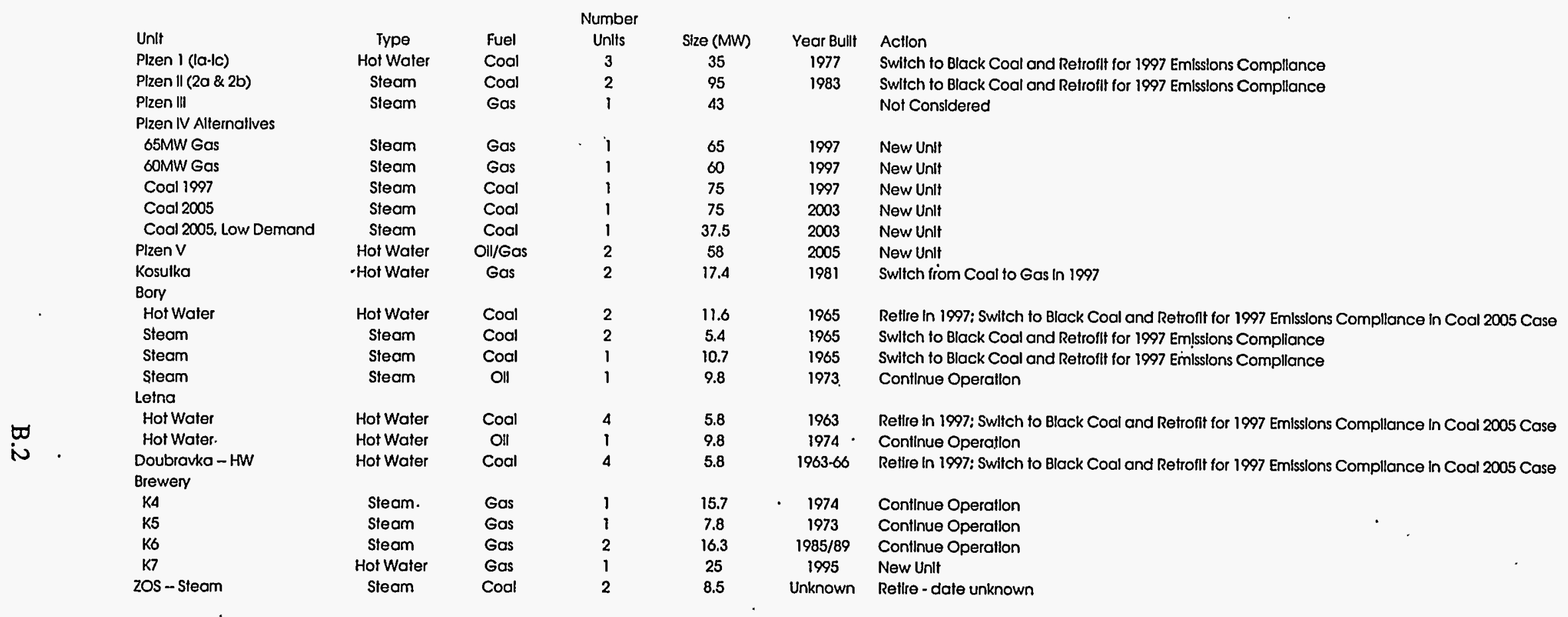


Table B.2. 65 MW Gas Supply Configuration

\begin{tabular}{|c|c|c|c|c|c|c|c|c|c|}
\hline & & & & $H I G$ & HDEMAI & & & & \\
\hline & 1992 & 1993 & 1994 & 1995 & 1996 & 1997 & 2000 & 2005 & 2010 \\
\hline Plzen la & 35 & 35 & 35 & 35 & 35 & 35 & 35 & & \\
\hline Plzen lb & 35 & 35 & 35 & 35 & 35 & 35 & 35 & & \\
\hline Plzen lc & 35 & 35 & 35 & 35 & 35 & 35 & 35 & & \\
\hline Plzen lla & 82.5 & 82.5 & 82.5 & 82.5 & 82.5 & 82.5 & 82.5 & 82.5 & 82.5 \\
\hline Plzen IIb & 82.5 & 82.5 & 82.5 & 82.5 & 82.5 & 82.5 & 82.5 & 82.5 & 82.5 \\
\hline Kosutka & 34.8 & 34.8 & 34.8 & 34.8 & 34.8 & 34.8 & 34.8 & 34.8 & 34.8 \\
\hline Bory | \& || & & & & & 23.2 & & & & \\
\hline Letna I-IV & & & & & 23.2 & & & & \\
\hline Letna V & & & & & 9.8 & & & & \\
\hline Doubravka l-IV & & - & & & 23.2 & & & & \\
\hline Plzen III & & & & & & & & & \\
\hline Plzen IV & & & . & & & 64.3 & 64.3 & 64.3 & 64.3 \\
\hline Plzen Va & & & & & & . & & 58 & 58 \\
\hline Plzen Vb & & & & & & & & 58 & 58 \\
\hline Total & 304.8 & 304.8 & 304.8 . & 304.8 & 384.2 & 369.1 & 369.1 & 380.1 & 380.1 \\
\hline Total w/o Largest & 222.3 & 222.3 & 222.3 & 222.3 & 301.7 & 286.6 & 286.6 & 297.6 & 297.6 \\
\hline & & & & LOI & VDEMAI & & & . & \\
\hline & 1992 & 1993 & 1994 & 1995 & 1996 & 1997 & 2000 & 2005 & 2010 \\
\hline Plzen la & 35 & 35 & 35 & 35 & 35 & 35 & 35 & & \\
\hline Plzen lb & 35 & 35 & 35 & 35 & 35 & 35 & 35 & & \\
\hline Plzen lc & 35 & 35 & 35 & 35 & 35 & 35 & 35 & & \\
\hline Plzen lla & 82.5 & 82.5 & 82.5 & 82.5 & 82.5 & 82.5 & 82.5 & 82.5 & 82.5 \\
\hline Plzen Illb & 82.5 & 82.5 & 82.5 & 82.5 & 82.5 & 82.5 & 82.5 & 82.5 & 82.5 \\
\hline Kosutka & 34.8 & 34.8 & 34.8 & 34.8 & 34.8 & 34.8 & 34.8 & 34.8 & 34.8 \\
\hline Bory | \& II & & & & & 23.2 & & & & \\
\hline Letna IIV & & & & & 23.2 & & & & \\
\hline Letna $V$ & & & & & 9.8 & & & & \\
\hline Doụbravka I-IV & & & & & 23.2 & & & & \\
\hline Pizén III & & & & & & & & & \\
\hline Plzen IV & & & & & & 64.3 & 64.3 & 64.3 & 64.3 \\
\hline PIzen Va & & & & & & & & 58 & 58 \\
\hline PIzen Vb & & & & & & & & & \\
\hline Total & 304.8 & 304.8 & 304.8 & 304.8 & 384.2 & 369.1 & 369.1 & 322.1 & 322.1 \\
\hline Total w/o Largest & 222.3 & 222.3 & 222.3 & 222.3 & 301.7 & 286.6 & 286.6 & 239.6 & 239.6 \\
\hline
\end{tabular}

\section{B.3}


Table B.3. 60 MW Gas Supply Configuration

HIGHDEMAND

Plzen la

Plzen lb

Plzen lc

PIzen lia

Pizen Ilb

Kosutka

Bory I \& II

Letna I-IV

Letna V

Doubravka I-IV

Plzen III

PIzen IV

Plzen Va

Plzen Vb

Total

Total w/o Largest

$\begin{array}{rrr}1992 & 1993 & 1994 \\ 35 & 35 & 35 \\ 35 & 35 & 35 \\ 35 & 35 & 35 \\ 82.5 & 82.5 & 82.5 \\ 82.5 & 82.5 & 82.5 \\ 34.8 & 34.8 & 34.8 \\ & & \end{array}$

$\begin{array}{rrrrrr}1995 & 1996 & 1997 & 2000 & 2005 & 2010 \\ 35 & 35 & 35 & 35 & & \\ 35 & 35 & 35 & 35 & & \\ 35 & 35 & 35 & 35 & & \\ 82.5 & 82.5 & 82.5 & 82.5 & 82.5 & 82.5 \\ 82.5 & 82.5 & 82.5 & 82.5 & 82.5 & 82.5 \\ 34.8 & 34.8 & 34.8 & 34.8 & 34.8 & 34.8 \\ & 23.2 & & & & \end{array}$

3048

$\begin{array}{rrrrrrrr} & & & & 48.2 & 48.2 & 48.2 & 48.2 \\ & & & & & & 58 & 58 \\ 304.8 & 304.8 & 304.8 & 384.2 & 353 & 353 & 58 & 58 \\ 222.3 & 222.3 & 222.3 & 301.7 & 270.5 & 270.5 & 281.5 & 281.5\end{array}$

Plzen la

Plzen lb

Plzen Ic

PIzen lla

Plzen llb

Kosutka

Bory I \& II

Letna I-IV

Letna $V$

Doubravka I-IV

$\begin{array}{lll}222.3 & 222.3 & 222.3\end{array}$

222.3

270.5

$27.5 \quad 281.5$

281.5

Plzen III

Plzen IV

Plzen Va

Pizen Vb

Total

Total w/o Largest

$\begin{array}{rrr}1992 & 1993 & 1994 \\ 35 & 35 & 35 \\ 35 & 35 & 35 \\ 35 & 35 & 35 \\ 82.5 & 82.5 & 82.5 \\ 82.5 & 82.5 & 82.5 \\ 34.8 & 34.8 & 34.8\end{array}$

LOW DEMAND

$\begin{array}{llllll}995 & 1996 & 1997 & 2000 & 2005 & 2010\end{array}$

$\begin{array}{llll}35 & 35 & 35 & 35 \\ 35 & 35 & 35 & 35\end{array}$

$\begin{array}{llll}35 & 35 & 35 & 35\end{array}$

$\begin{array}{llll}35 & 35 & -35 & 35\end{array}$

$\begin{array}{llll}82.5 & 82.5 & 82.5 & 82.5\end{array}$

$\begin{array}{llll}82.5 & 82.5 & 82.5 & 82.5\end{array}$

$34.8 \quad 34.8$

23.2

23.2

9.8

23.2

$\begin{array}{ll}82.5 & 82.5 \\ 34.8 & 34.8\end{array}$

$304.8 \quad 304.8 \quad 304.8$

$222.3 \quad 222.3 \quad 222.3$

304.8

222.3

384.2

301.7

48.2

$\begin{array}{lll}48.2 & 48.2 \quad 48.2\end{array}$

58,58

$\begin{array}{llll}353 & 353 & 306 & 306\end{array}$

$\begin{array}{llll}270.5 & 270.5 & 223.5 & 223.5\end{array}$

B.4 
Table B.4. Coal 1997 Supply Configuration

\begin{tabular}{|c|c|c|c|c|c|c|c|c|c|}
\hline & \multicolumn{9}{|c|}{ HIGH DEMAND } \\
\hline & 1992 & 1993 & 1994 & \multicolumn{2}{|c|}{$1995 \quad 1996$} & \multirow{2}{*}{1997} & \multirow{2}{*}{$\begin{array}{r}2000 \\
35\end{array}$} & \multirow{2}{*}{2005} & \multirow[t]{2}{*}{2010} \\
\hline Pizen la & 35 & 35 & 35 & 35 & 35 & & & & \\
\hline Plzen lb & 35 & 35 & 35 & 35 & 35 & 35 & 35 & & \\
\hline Plzen lc & 35 & 35 & 35 & 35 & 35 & 35 & 35 & & \\
\hline Pizen lia & 82.5 & 82.5 & 82.5 & 82.5 & 82.5 & 82.5 & 82.5 & 82.5 & 82.5 \\
\hline Pizen llb & 82.5 & 82.5 & 82.5 & 82.5 & 82.5 & 82.5 & 82.5 & 82.5 & 82.5 \\
\hline Kosutka & 34.8 & 34.8 & 34.8 & 34.8 & 34.8 & 34.8 & 34.8 & 34.8 & 34.8 \\
\hline Bory | \& II & & & & & 23.2 & & & & \\
\hline Letna I-IV & & & & & 23.2 & & & & \\
\hline Letna V & & & & & 9.8 & & & & \\
\hline Doubravka I-IV & & & & & 23.2 & & & & \\
\hline Plzen ill & & & & & & & & & \\
\hline Pizen IV & & & & & & 75 & 75 & 75 & 75 \\
\hline Pizen Va & & & & & & & & 58 & 58 \\
\hline Plzen Vb & & & & & & & & 58 & 58 \\
\hline Total & 304.8 & 304.8 & 304.8 & 304.8 & 384.2 & 379.8 & 379.8 & 390.8 & 390.8 \\
\hline \multirow[t]{3}{*}{ Total w/o Largest } & 222.3 & 222.3 & 222.3 & 222.3 & 301.7 & 297.3 & 297.3 & 308.3 & 308.3 \\
\hline & \multicolumn{9}{|c|}{ LOW DEMAND } \\
\hline & 1992 & 1993 & 1994 & 1995 & 1996. & 1997 & 2000 & 2005 & 2010 \\
\hline Pizen la & 35 & 35 & 35 & 35 & 35 & 35 & 35 & & \\
\hline Plzen lb & $35^{\circ}$ & 35 & 35 & 35 & 35 & 35 & 35 & & \\
\hline Plzen lc & 35 & 35 & 35 & 35 & 35 & 35 & 35 & & \\
\hline PIzen lla & 82.5 & 82.5 & 82.5 & 82.5 & 82.5 & 82.5 & 82.5 & 82.5 & 82.5 \\
\hline PIzen llb & 82.5 & 82.5 & 82.5 & 82.5 & 82.5 & 82.5 & 82.5 & 82.5 & 82.5 \\
\hline Kosutka & 34.8 & 34.8 & 34.8 & 34.8 & 34.8 & 34.8 & 34.8 & 34.8 & 34.8 \\
\hline Bory | \& II & & & & & 23.2 & & & & \\
\hline Letna I-IV & & & & & 23.2 & & & & \\
\hline Letna V & & & & & 9.8 & & & & \\
\hline Doubravka I-IV & & & & & 23.2 & & & & \\
\hline PIzen III & & & & & & & & & \\
\hline Plzen IV & & & & & & 75 & 75 & 75 & 75 \\
\hline Plzen Va & & & & & & & & 58 & 58 \\
\hline Plzen Vb & & & & & & & & & \\
\hline Total & 304.8 & 304.8 & 304.8 & 304.8 & 384.2 & 379.8 & 379.8 & 332.8 & 332.8 \\
\hline Total w/o Largest & 222.3 & 222.3 & 222.3 & 222.3 & 301.7 & 297.3 & 297.3 & 250.3 & 250.3 \\
\hline
\end{tabular}

B. 5 
Table B.5. Coal 2005 Supply Configuration

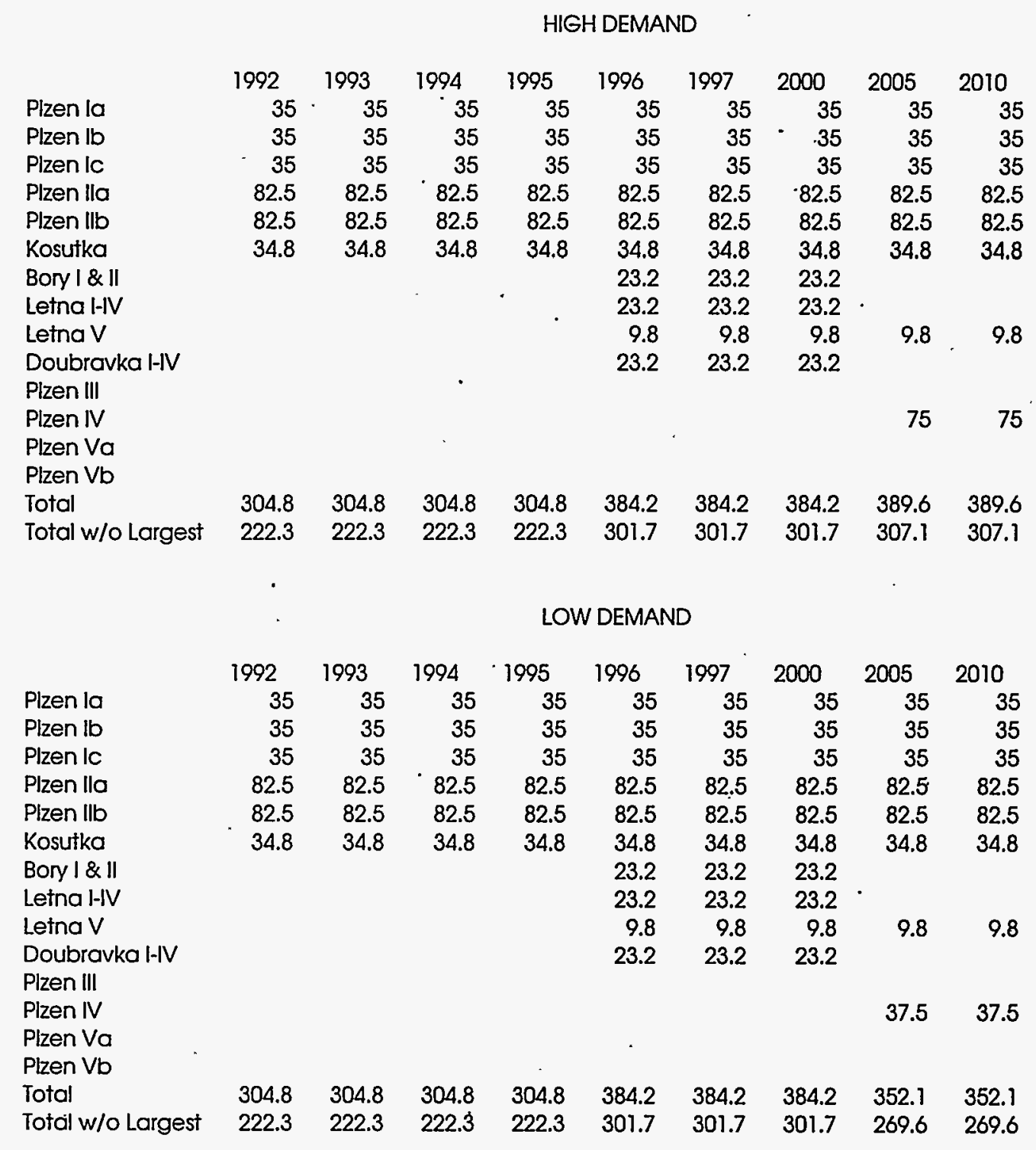




\section{Appendix C}

\section{Load/Supply Capacity Margins}




\section{Appendix C}

\section{Load/Supply Capacity Margins}

The analysis to integrate the supply and efficiency resource options is based upon the ability to meet system loads. Following the methodology used in the supply assessment, the load scenarios are matched to the alternative supply resource configurations to provide the net capacity surplus or deficit for each combination. A modest capacity surplus provides for future system expansion with existing capacity, and a significant surplus would indicate that the investment in resources may be deferred. A deficit situation indicates that additional capacity may be required to serve the load if reliability and service are important.

The four load scenarios from Tables A.5 and A.6, the moderate and full system expansion cases, are matched to the capacity configurations in Tables B.2 - B.5. The high demand portions of the load tables are matched to the high demand capacity scenario; this is repeated for the low demand portions

of the tables. A conservative approach is taken in this process to ensure system reliability and service as follows:

1. On the load side, the hot water and steam loads are increased by $10 \%$ and $5 \%$, respectively, over the values shown to account for an extraordinary peak, and this adjusted load is then reduced by $15 \%$ to reflect a short term reduction in quality of service in a peak period. In fact, Czech regulations permit a service reduction of about $20 \%$. So, in the moderate system expansion case (Table A.5), high demand without programmatic efficiency, the $295.4 \mathrm{MW}$, hot water load in the year 2010 is adjusted to $276.2 \mathrm{MW}_{\mathrm{t}}$ and the $99.6 \mathrm{MW}_{\mathrm{t}}$ steam load is adjusted to $88.9 \mathrm{MW}_{\mathrm{t}}$. The total load for the net capacity calculation is then $365.1 \mathrm{MW}_{\mathrm{t}}$.

2. On the supply side, the total capacity without the largest unit is used to reflect the ability of the system to meet load with the largest unit out of service. In addition, $56.1 \mathrm{MW}_{\mathrm{t}}$ of capacity assumed to be available from the brewery is added. So, in the case of the $65 \mathrm{MW}$ gas supply configuration for the high load, the available capacity is $353.7 \mathrm{MW}_{\imath}$.

For the above example, a deficit of about $11 \mathrm{MW}_{\mathrm{t}}$ of capacity exists in the $65 \mathrm{MW}$ gas supply option in the year 2010 to meet the projected system load. The net capacities for all 32 load and capacity combinations are shown in Table C.1.

The integrated analysis did not attempt to adjust the capacity configurations to reduce significant surpluses or deficits. However, in some cases, the capacity configuration and load scenarios 
Table C.1. Heat Supply Peak Capacity Surplus/Deficit by Supply and Load Combination

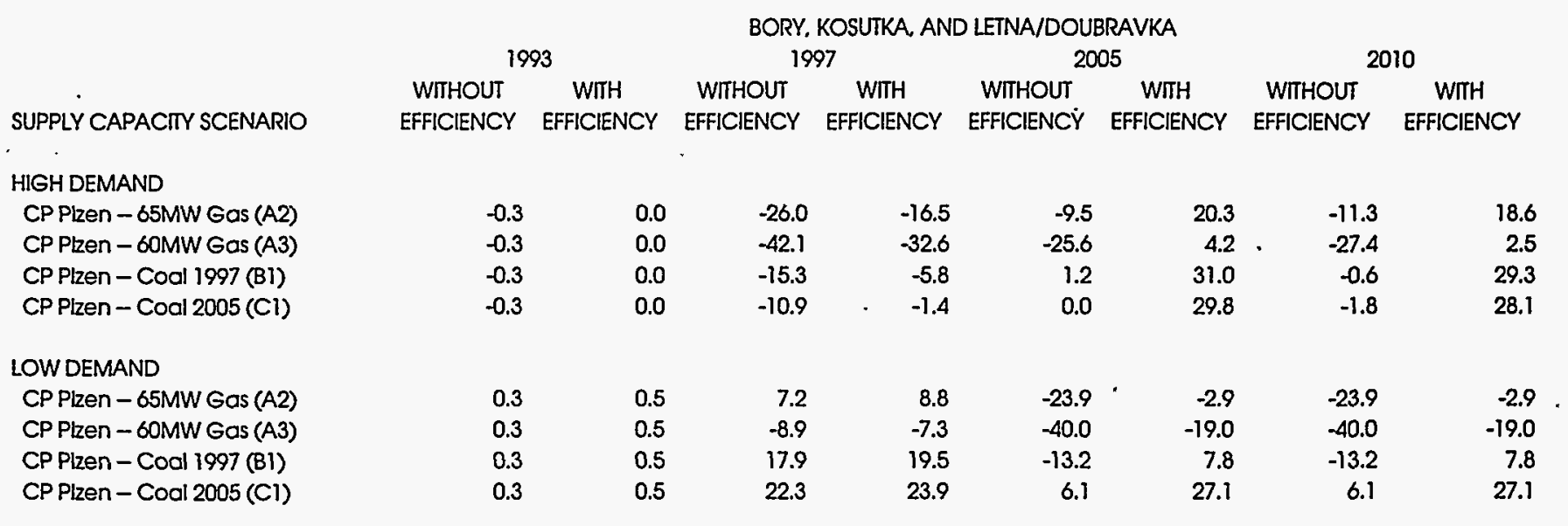

BORY, KOSUTKA, LETNA/DOUBRAVKA, AND SVETOVAR

SUPPLY CAPACITY SCENARIO

WITHOUT
EFFICIENCY EFFICIENCY EFH

WITHOUT 1997 WITH WITHOUT 2005 WITH

WITHOUT 2010 WITH EFFICIENCY EFFICIENCY EFFICIENCY EFFICIENCY EFFICIENCY EFFICIENCY

HIGH DEMAND

CP Plzen - 65MW Gas (A2)

CP Plzen - 60MW Gas (A3)

CP Plzen - Coal 1997 (BI)

CP Plzen - Cool 2005 (Cl)

$\begin{array}{rrrrrrrr}-0.3 & 0.0 & -49.1 & -39.0 & -32.3 & 0.0 & -34.1 & -1.7 \\ -0.3 & 0.0 & -65.2 & -55.1 & -48.4 & -16.1 & -50.2 & -17.8 \\ -0.3 & 0.0 & -38.4 & -28.3 & -21.6 & 10.7 & -23.4 & 9.0 \\ -0.3 & 0.0 & -34.0 & -23.9 & -22.8 & -9.5 & -24.6 & 7.8\end{array}$

LOWDEMAND

CP Plzen - 65MW Gas (A2)

CP Pizen - 6OMW Gas (A3)

CP PIzen - Coal 1997 (BI)

CP Plzen - Coal 2005 (C1)

$\begin{array}{ll}0.3 & 0.5 \\ 0.3 & 0.5 \\ 0.3 & 0.5 \\ 0.3 & 0.5\end{array}$

Net capacity is calculated as follows:

Total supply capacity (Appendix B) without the largest unit plus 56.1MWt capacity available from the brewery.

Minus hot water load (App. A) increased by $10 \%$ to reflect extroardinary demand and reduced by $15 \%$ to reflect high demand service reductlon.

Minus steam load (App. A) increased by $5 \%$ to reflect extroardinary demand and reduced by $15 \%$ to reflect high demand service reduction. 
combinations were not analyzed because of the magnitude of the deficit. The selection for the supply/load combinations follows, with the discussion focusing on the values in the 2005-2010 time period.

\section{Moderate System Expansion}

High Demand Without and With Efficiency. It would appear that the load could reasonably be met with the $65 \mathrm{MW}$ gas configuration either with or without efficiency because the deficit of $11 \mathrm{MW}_{\mathrm{t}}$ (surplus of $19 \mathrm{MW}$ ) is about only about $3 \%$ (5\%). of the projected load. However, in the case of the $60 \mathrm{MW}$ gas supply configuration, the deficit accounts for about $7 \%$ of the projected load and the surplus in the efficiency scenario is near zero. In the two coal configurations, the deficit is minimal without efficiency and increases to about $8 \%$ of the projected load when programmatic efficiency is introduced.

While it would have been desirable to adjust the system configurations to analyze a closer match of capacity to load in both load scenarios (without and with programmatic efficiency), program constraints did not allow for this. All eight cases were analyzed with the surplus or deficit as shown.

Low Demand Without and With Efficiency. Again, the two gas supply configurations exhibit deficits even when programmatic efficiency is considered. Of the two coal options, the 1997 configuration appears to be an acceptable match to the load either without or with programmatic efficiency, and the 2003 configuration exhibits a surplus in both load scenarios.

In this case, the high demand capacity configurations for the two gas supply configurations were analyzed for the load scenario without efficiency-this produced capacity surpluses of $34 \mathrm{MW}_{\mathrm{t}}$ and $18 \mathrm{MW}_{\mathrm{t}}$ for the $65 \mathrm{MW}_{\mathrm{t}}$ and $60 \mathrm{MW}$ gas configurations, respectively. The low demand capacity configurations were retained for the load scenario with efficiency, but not analyzed because of project constraints.

\section{Full System Expansion}

High Demand Without and With Efficiency. In all without-efficiency combinations, a significant capacity deficit exists. In the with-efficiency cases, the deficit is reduced for the two gas supply configurations and becomes a slight surplus for the two coal-fired configurations.

Given the size of the deficits in the without-efficiency load scenario, no cases were analyzed as this would have required adding additional supply capacity. All four high demand capacity configurations were analyzed for the load scenario with efficiency, with the net capacities as shown.

Low Demand Without and With Efficiency. Again, a significant capacity deficit exits for all four of the low demand capacity configurations paired with the load scenario without efficiency. The deficits exist for all but the 2003 coal supply configuration in the load scenario with efficiency.

In the load scenario without efficiency, the high load capacity configurations were selected for analysis. This provides a surplus of $15 \mathrm{MW}_{\mathrm{t}}$ for the $65 \mathrm{MW}_{\mathrm{t}}$ gas configuration, a deficit of $2 \mathrm{MW}_{\mathrm{t}}$ 
Low Demand Without and With Efficiency. Again, a significant capacity deficit exits for all four of the low demand capacity configurations paired with the load scenario without efficiency. The deficits exist for all but the 2003 coal supply configuration in the load scenario with efficiency.

In the load scenario without efficiency, the high load capacity configurations were selected for analysis. This provides a surplus of $15 \mathrm{MW}_{\mathrm{t}}$ for the $65 \mathrm{MW}_{\mathrm{t}}$ gas configuration, a deficit of $2 \mathrm{MW}_{\mathrm{t}}$ for the $6 \mathrm{MW}_{\mathrm{t}}$ gas configuration, and creates surpluses of $9 \mathrm{MW}_{\mathrm{t}}$ and $8 \mathrm{MW}_{\mathrm{t}}$ for the 1995 and 2003 coal supply configurations, respectively. In the case of the load scenario with efficiency, the high load gas supply configurations were again analyzed; this provides surpluses of $38 \mathrm{MW}_{\mathrm{t}}$ and $22 \mathrm{MW}_{\mathrm{t}}$ for the 65 and $60 \mathrm{MW}$, gas supply configurations. The low demand coal configurations were retained with the net capacities as shown.

A critical ending note is that the authors believe the analyses conducted are sufficient to indicate the relative merits of the supply and efficiency resources. Although it would be desirable from a standpoint of completeness to have examined each supply and load combination for a zero capacity deficit/surplus and examined the six missing pairs, it is not felt that the additional information would change the relative merits of the combinations examined. 


\section{Appendix D}

Analysis Assumptions 


\section{Appendix D}

\section{Analysis Assumptions}

Most of the analysis and assumptions supporting the integrated analysis were drawn from the supply and efficiency assessments. Discussions with staff from the City of Plzeñ resulted in the following revisions:

- Electricity production from the existing $55 \mathrm{MW}_{\mathrm{e}}$ unit was set at about 160,000 MWh/year and sales were set at about $130,000 \mathrm{MWh} /$ year. These agree historical levels and are felt to be the best the unit could achieve.

- Steam production levels were set at about $240,000 \mathrm{MWh} /$ year. These are in line with historical production and sales levels and with the supply assessment data after removing steam purchases from the brewery.

- The cost streams for the four alternatives are shown in Tables D.1 through D.8. Major additions reflect the cost of retirements, ash disposal, and heat line extension for the Letna/Doubravka and Svetovar connections.

- The efficiency potential is set to reduce heat production by $10 \%$ and end-use consumption by $15 \%$ at the cost developed in the efficiency assessment. This is felt to be a conservative estimate of the customer-side potential and is based upon results of the demonstration and evaluation of similar measures being conducted in Krakow, Poland.

The combined steam and heat price calculation is structured as follows:

- Annual revenue is set equal to the sum of principal, interest, change in working capital, operations and maintenance, return on equity/investment, and taxes; where taxes equal the tax rate times revenue minus operations and maintenance, depreciation, and interest. The revenue is then reduced by the loan receipts and the after-tax electricity revenue to provide the revenue needed from steam and heat sales for operation.

- Adjusted revenue is then divided by the combined steam and heat sales to provide the price needed for operation. 
Table D.1. Cost Stream for System Upgrade, Moderate System Expansion (Million Kc,) Coal 2003

\begin{tabular}{|c|c|c|c|c|c|c|c|c|c|c|c|c|c|c|c|c|c|c|c|c|}
\hline & 1993 & 1994 & 1995 & 1996 & 1997 & 1998 & 1999 & 2000 & 2001 & 2002 & 2003 & 2004 & 2005 & 2006 & 2007 & 2008 & 2009 & 2010 & Total & $1993-2000$ \\
\hline Bory & & & 4.1 & 4.1 & & & & & & & & & 28.3 & & & & & & 36.5 & 8.2 \\
\hline Lelna & & & 5.8 & 5.8 & & & & & & & & & 35.1 & & & & & & 46.7 & 11.6 \\
\hline Doubravka & & & 4.1 & 4.1 & & & & & & & & & 35.1 & & & . & & & 43.3 & 8.2 \\
\hline Svetovar & & & 5.8 & 5.8 & & & & & & & & & & & & & & & 11.6 & 11.6 \\
\hline Kosutka & & & & 10.6 & & & & & & & & & & & & & & & 10.6 & 10.6 \\
\hline East I Extension & & & 25.0 & 50.0 & & & & & & & & & & & & & & & 75.0 & 75.0 \\
\hline System Improvement & 5.3 & 23.5 & 60.8 & 27.5 & 13.8 & 7.2 & 7.2 & 7.2 & 0.9 & 0.9 & 0.8 & 0.9 & 0.9 & 0.7 & 0.7 & 0.7 & 0.7 & 0.7 & 160.5 & 152.5 \\
\hline System Improvement" & 1.7 & 7.1 & 22.9 & 5.3 & 3.7 & 0.4 & 0.4 & 0.4 & 0.2 & 0.2 & 0.2 & 0.2 & 0.2 & & & & & & 42.9 & 41.9 \\
\hline Plzen 1 & & & 10.7 & 10.7 & & & & & & & & & & & & & & & 21.4 & 21.4 \\
\hline Plzen II & & & 225.0 & 225.0 & & & & & & & & & & & & & & . & 450.0 & 450.0 \\
\hline Ash Disposal & & & 10.0 & 15.0 & 25.0 & & & & & & & & & & & & & & 50.0 & 50.0 \\
\hline PIzen III & & & & & & & & & & & & & & & & & & & 0.0 & 0.0 \\
\hline Plzen IV & & & & & & & & & 534.0 & 534.0 & & & & & & & & & 1068.0 & 0.0 \\
\hline Plzen IV" & & & & & & & & & 307.0 & 307.0 & & & & & & & & & 614.0 & 0.0 \\
\hline Plzen V & & & & & & & & & & & 91.5 & 91.5 & & & & & & & 183.0 & 0.0 \\
\hline Plzen V* & & & & & & & & & & & 56.4 & 56.4 & & & & & & & 112.8 & 0.0 \\
\hline Tolal -- Kc & 5.3 & 23.5 & 351.3 & 358.6 & 38.8 & 7.2 & 7.2 & 7.2 & 534.9 & 534.9 & 92.4 & 924 & 99.4 & 0.7 & 0.7 & 0.7 & 0.7 & 0.7 & 2156.6 & 799.1 \\
\hline Tolal .. \$ & 0.19 & 0.84 & 12.55 & 12.81 & 1.39 & 0.26 & 0.26 & 0.26 & 19.10 & 19.10 & 3.30 & 3.30 & 3.55 & 0.03 & 0.03 & 0.03 & 0.03 & 0.03 & 77.02 & 28.54 \\
\hline Tolal -- Kc' & 1.7 & 7.1 & 13.4 & 338.4 & 28.7 & 0.4 & 0.4 & 0.4 & 307.2 & 307.2 & 56.6 & 56.6 & 98.7 & 0.0 & 0.0 & 0.0 & 0.0 & 0.0 & 1514.8 & 688.5 \\
\hline Tolal -. \$" & 0.08 & 0.25 & 11.19 & 12.01 & 1.03 & 0.01 & 0.01 & 0.01 & 10.97 & 10.97 & 2.02 & 2.02 & 3.53 & 0.00 & 0.00 & 0.00 & 0.00 & 0.00 & 54.10 & 24.59 \\
\hline
\end{tabular}


Table D.2. Cost Stream for System Upgrade, Moderate System Expansion (Million Kc,) Coal 1997

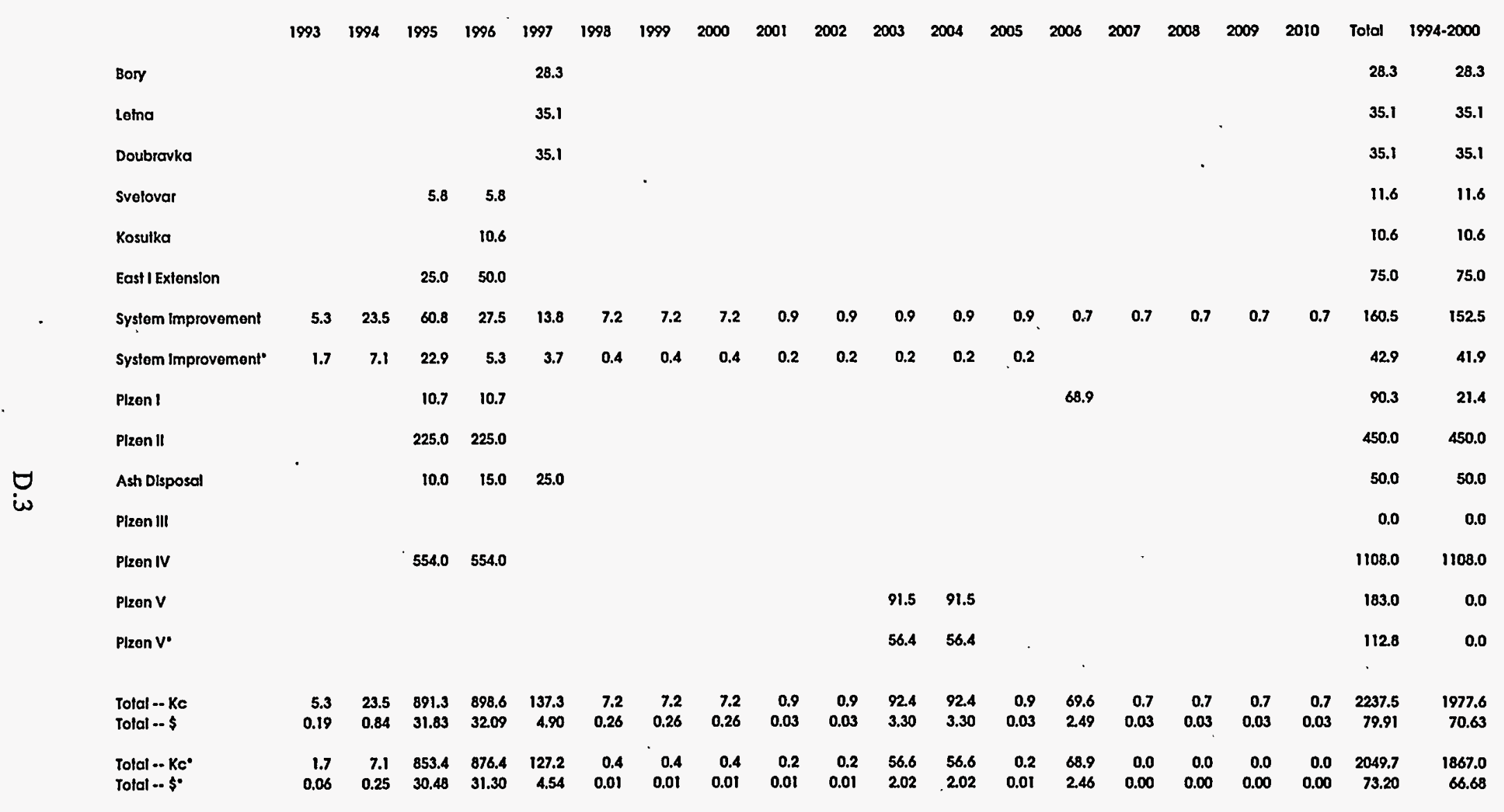

- Notos cost stroams for low domand sconario. 
Table D.3. Cost Stream for System Upgrade, Moderate System Expansion (Million Kc), 65MW Gas

\begin{tabular}{|c|c|c|c|c|c|c|c|c|c|c|c|c|c|c|c|c|c|c|c|c|}
\hline & 1993 & 1994 & 1995 & 1996 & 1997 & 1998 & 1999 & 2000 & 2001 & 2002 & 2003 & 2004 & 2005 & .2008 & 2007 & 2008 & 2009 & 2010 & Total & 1994-2000 \\
\hline Bory & & & & & 28.3 & & & & & & & & & & & & & & 28.3 & 28.3 \\
\hline Letna & & & & & 35.1 & & & & & & & & & & & & & & 35.1 & 35.1 \\
\hline Doubravka & & & & & 35.1 & & & & & & & & & & & & & & 35.1 & 35.1 \\
\hline Svefovar & & & 5.8 & 5.8 & & & & & & & & & & & & & & & 11.6 & 11.6 \\
\hline Kosutka & & & & 10.6 & & & & & & & & & & & & & & & 10.6 & 10.6 \\
\hline System Improvement & 5.3 & 23.5 & 60.8 & 27.5 & 13.8 & 7.2 & 7.2 & 7.2 & 0.9 & 0.9 & 0.9 & 0.9 & 0.9 & 0.7 & 0.7 & 0.7 & 0.7 & 0.7 & 160.5 & 152.5 \\
\hline System Improvement" & 1.7 & 7.1 & 22.9 & 5.3 & 3.7 & 0.4 & 0.4 & 0.4 & 0.2 & 0.2 & 0.2 & 0.2 & 0.2 & & & & & & 42.9 & 41.9 \\
\hline Plzen I & & & 10.7 & 10.7 & & & & & & & & & & 68.9 & & & & & 90.3 & 21.4 \\
\hline Plzon II & & & 225 & 225 & & & & & & & & & & & & & & & 450 & 450 \\
\hline Ash Dlsposal & & & 10 & 15 & 25 & & - & & & & & . & & & & & & & 50 & 50 \\
\hline Plzen IV & & & 708 & 708 & & & & & & & & & & & & . & & & 1412 & 1412 \\
\hline Plzen V & & & & & & & & & & & 91.5 & 91.5 & & & & & & & 183 & 0 \\
\hline Plzen V• & & & & & & & & & & & 56.4 & 56.4 & & & & & & & 112.8 & 0 \\
\hline Total -- Ke & -5.3 & 23.5 & 1043.3 & 1050.6 & 137.3 & 7.2 & 7.2 & 7.2 & 0.9 & 0.9 & 92.4 & 92.4 & 0.9 & 69.6 & 0.7 & 0.7 & 0.7 & 0.7 & 2541.5 & 2281.6 \\
\hline Total -- \$ & 0.19 & 0.84 & 37.26 & 37.52 & 4.90 & 0.26 & 0.26 & 0.26 & 0.03 & 0.03 & 3.30 & 3.30 & 0.03 & 2.49 & 0.03 & 0.03 & 0.03 & 0.03 & 90.77 & 81.49 \\
\hline Tolal - Kc & 1.7 & 7.1 & 1005.4 & 1028.4 & 127.2 & 0.4 & 0.4 & 0.4 & 0.2 & 0.2 & 58.6 & 56.6 & 0.2 & 68.9 & 0.0 & 0.0 & 0.0 & 0.0 & 2353.7 & 2171.0 \\
\hline Tolal $=\$$ & 0.06 & 0.25 & 35.91 & 36.73 & 4.54 & 0.01 & 0.01 & 0.01 & 0.01 & 0.01 & 2.02 & 2.02 & 0.01 & 2.46 & 0.00 & 0.00 & 0.00 & 0.00 & 84.06 & 77.54 \\
\hline
\end{tabular}


Table D.4. Cost Stream for System Upgrade, Moderate System Expansion (Million Kc), 60MW Gas

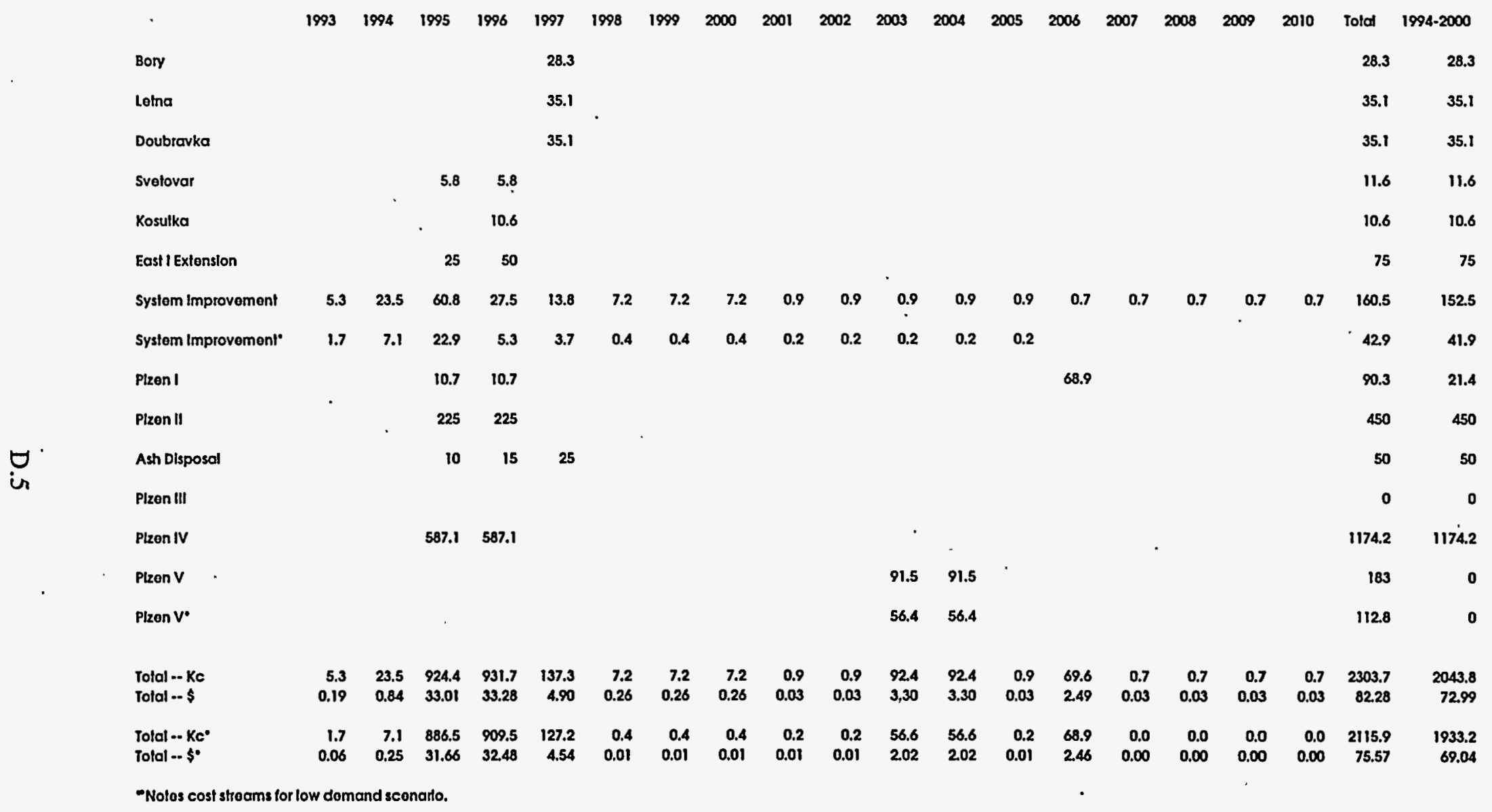


Table D.5. Cost Stream for System Upgrade, Full System Expansion (Million Kc,) Coal 2003

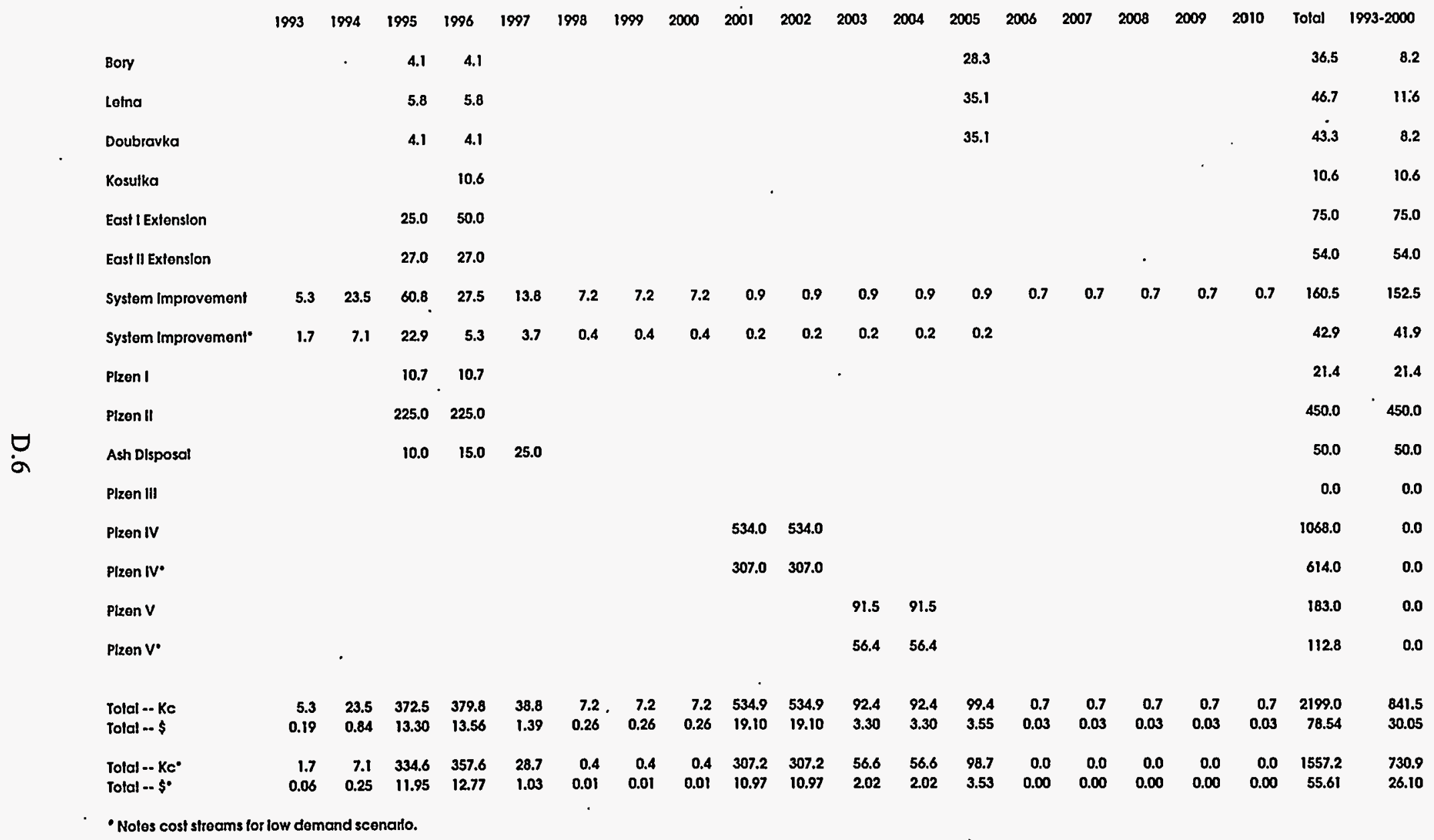


Table D.6. Cost Stream for System Upgrade, Full System Expansion (Million Kc,) Coal 1997

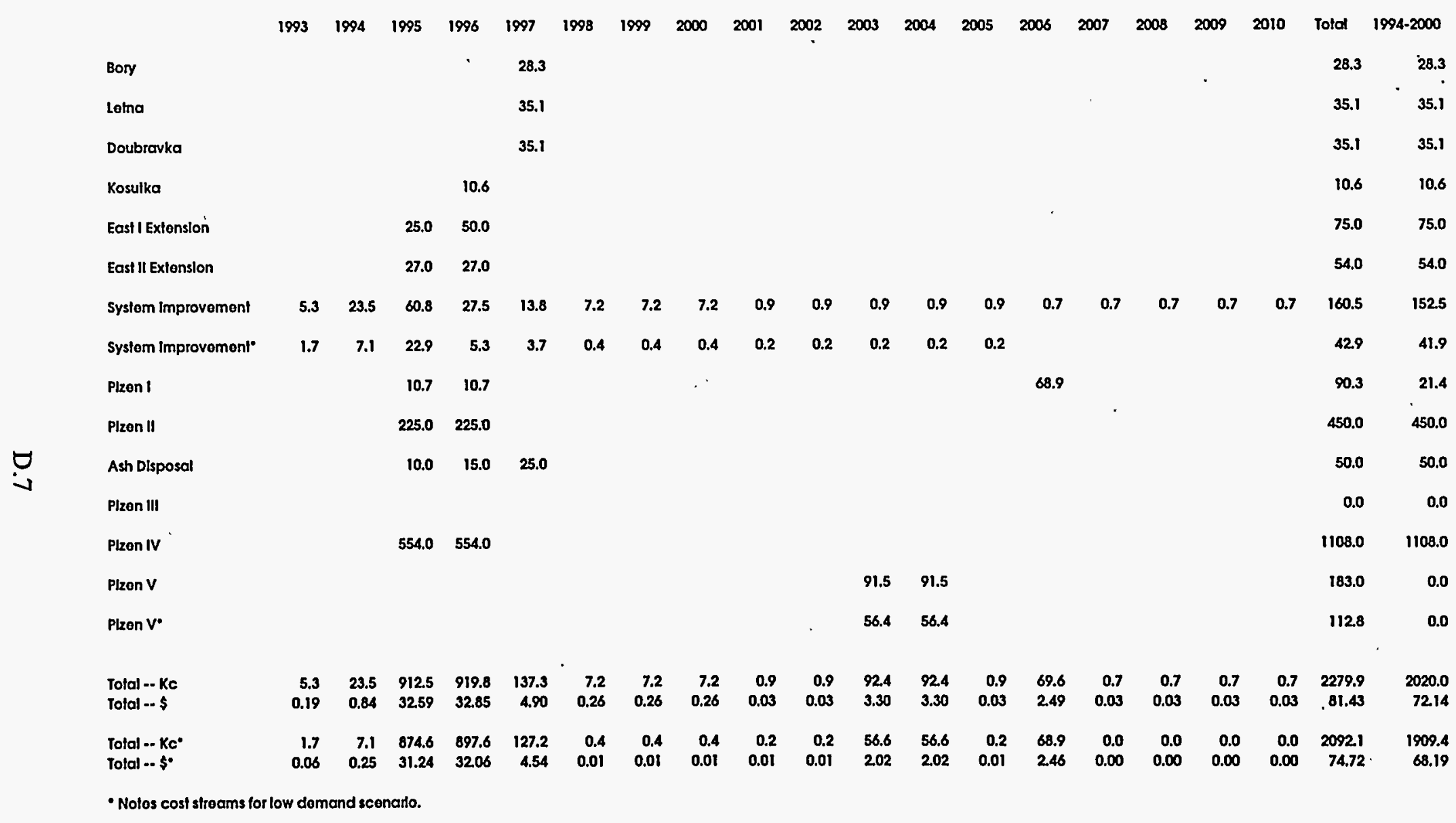


Table D.7. Cost Stream for System Upgrade, Full System Expansion (Million Kc,) 65MW Gas

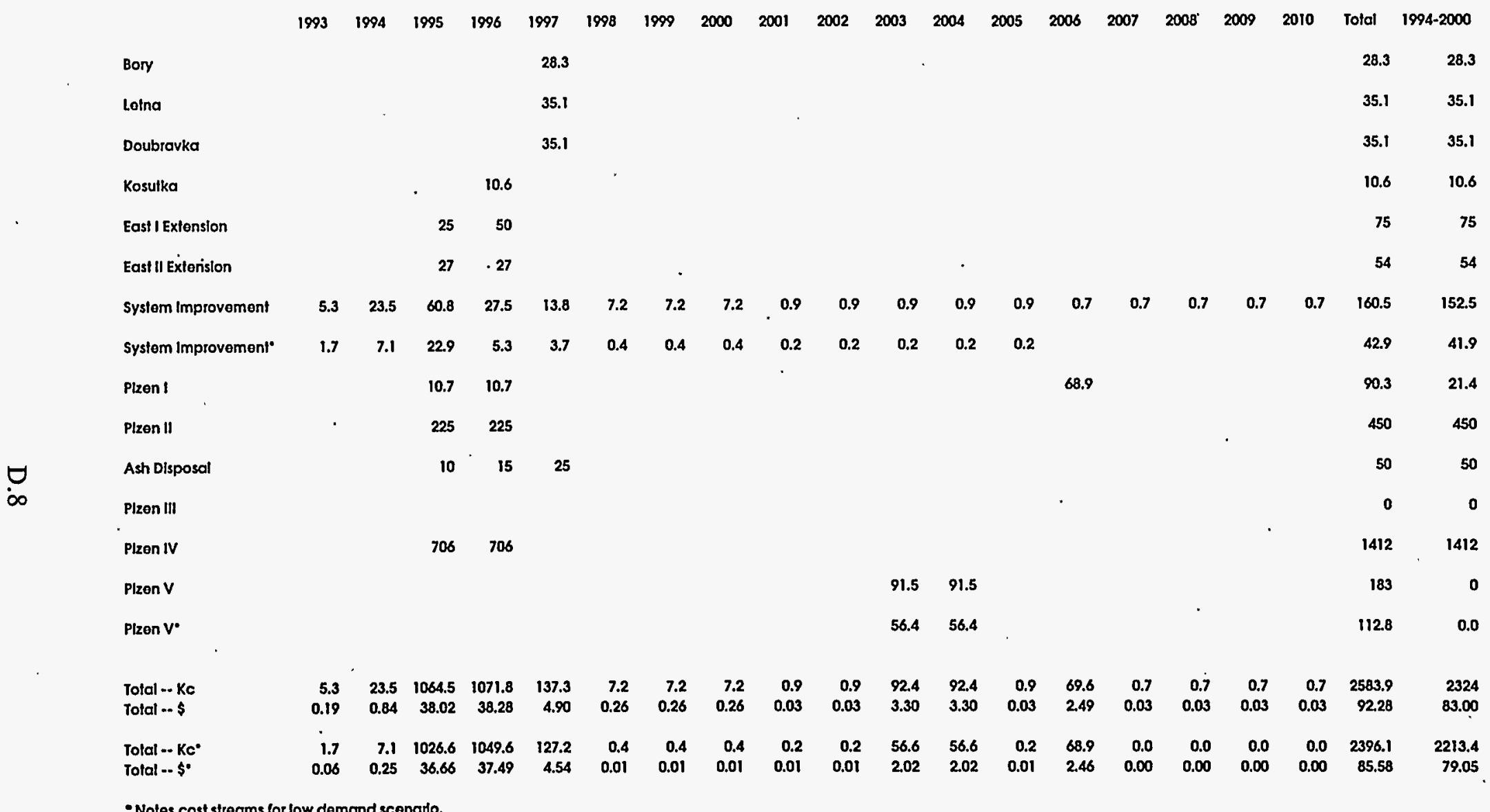


Table D.8. Cost Stream for System Upgrade, Full System Expansion (Million Kc,) 60MW Gas

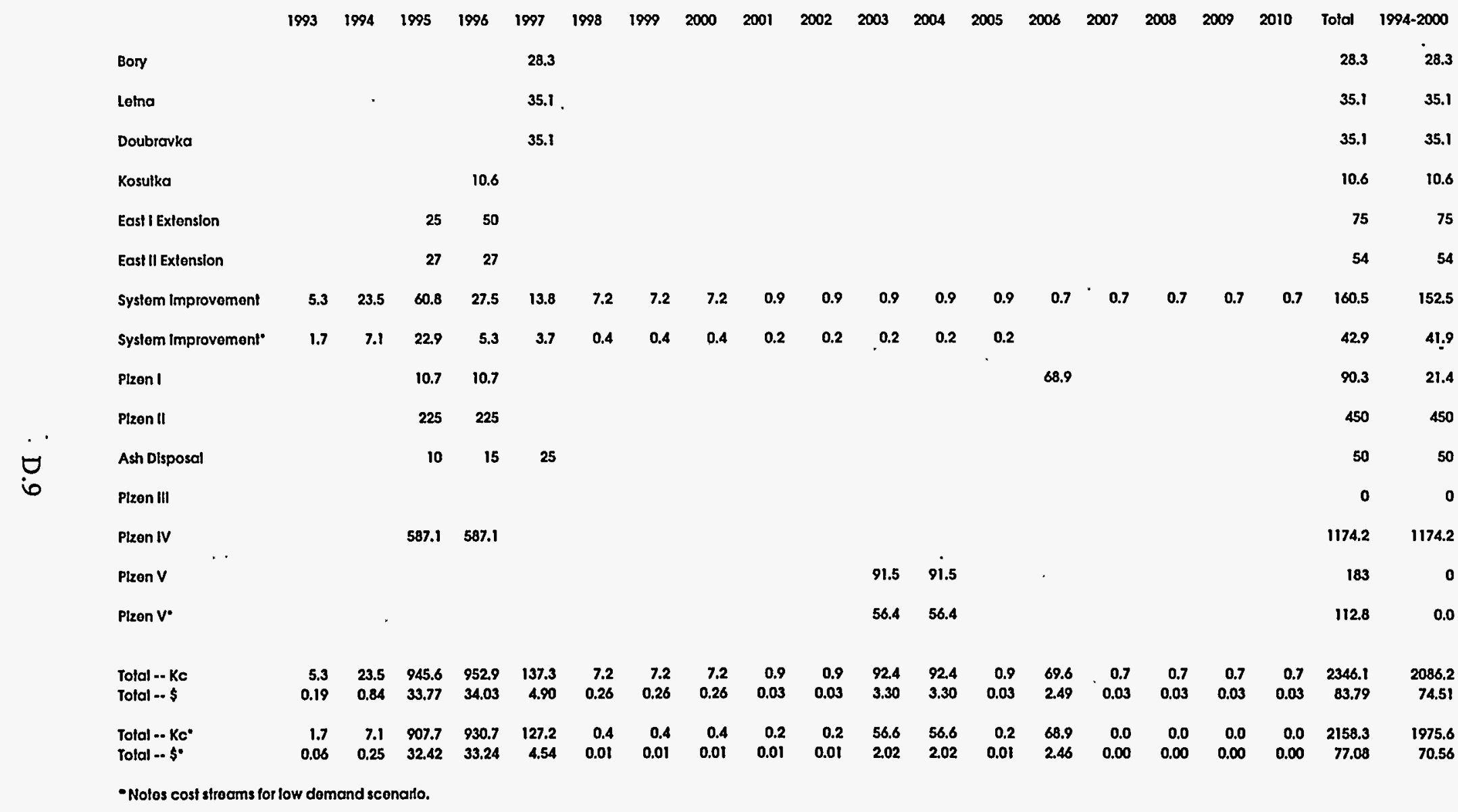


The following assumptions were used in the price calculation:

- Values are expressed in real terms.

- Capital and efficiency are debt financed.

- Capital is depreciated on a straight line basis over 25 years.

- Efficiency is expensed in the current year.

- Efficiency is implemented over a 10-year period.

- $\quad$ Real annual interest rate of $7 \%$.

- Loan term of 8 years.

- Real annual discount rate of $10 \%$.

- Tax rate of $45 \%$. 